\title{
Multiple Roles of the Y Chromosome in the Biology of Drosophila melanogaster
}

\author{
Roberto Piergentili \\ Dipartimento di Biologia e Biotecnologie, Sapienza - Università di Roma, Italia \\ E-mail: roberto.piergentili@uniroma1.it
}

Received February 2, 2010; Revised July 2, 2010; Accepted August 4, 2010; Published September 1, 2010

The $\mathrm{X}$ and $\mathrm{Y}$ chromosomes of Drosophila melanogaster were the first examples of chromosomes associated with genetic information. Thanks to the serendipitous discovery of a male with white eyes in 1910, T.H. Morgan was able to associate the $X$ chromosome of the fruit fly with a phenotypic character (the eye color) for the first time. A few years later, his student, C.B. Bridges, demonstrated that XO males, although phenotypically normal, are completely sterile. This means that the $X$ chromosome, like the autosomes, harbors genes that control several phenotypic traits, while the $Y$ chromosome is important for male fertility only. Notwithstanding its long history almost 100 years in terms of genetic studies - most of the features of the $Y$ chromosome are still a mystery. This is due to the intrinsic nature of this genetic element, namely, (1) its molecular composition (mainly transposable elements and satellite DNA), (2) its genetic inertia (lack of recombination due to its heterochromatic nature), (3) the absence of homology with the $X$ (with the only exception of the nucleolar organizer), (4) the lack of visible phenotypes when it is missing (indeed, except for their sterility, XO flies are normal males), and (5) its low density as for protein-coding sequences (to date, only 13 genes out of approximately 14,000 have been mapped on this chromosome in $D$. melanogaster, i.e., $\sim 0.1 \%$ of the total). Nonetheless, a more accurate analysis reveals that this chromosome can influence several complex phenotypes: (1) it has a role in the fertility of both sexes and viability of males when over-represented; (2) it can unbalance the intracellular nucleotide pool; (3) it can interfere with the gene expression either by recruiting proteins involved in chromatin remodeling (PEV) or, to a higher extent, by influencing the expression of up to 1,000 different genes, probably by changing the availability of transcription factors; (4) it plays a major role (up to 50\%) in the resistance to heat-induced male sterility; (5) it affects the behavior; and (6) it plays a role in genetic imprinting. In the present paper, all these Y-related phenotypes are described and a potential similarity with the human $Y$ chromosome is drawn.

KEYWORDS: constitutive heterochromatin, lampbrush-like loops, Homo sapiens Y chromosome, triplex, evolution, Drosophila miranda

\footnotetext{
${ }^{*}$ I dedicate this paper to my late colleague Nikolaj Junakovic.
} 


\section{WHAT IS A "GENE"?}

The first definition of the word "gene" is as old as the year 1909. Wilhelm Johannsen first used it[1] to name the "inheritable factors" causing variation in visible traits, which had been discovered by the famous experiments of Gregor Mendel[2]. Since then, scientific research has better defined these factors, but, in turn, has also complicated the definition itself of "gene". To date, there is still no agreement about the "exact" meaning of the word "gene" $[3,4,5]$. Experiments performed by T.H. Morgan in 1910 and by A.H. Sturtevant in 1913, which are summarized in a famous book published in 1915[6], changed the definition of "gene" as a discrete unit of heredity into a physical "locus", since it is possible to map any gene, relatively to the others, in any given chromosome. In 1909, Sir A.E. Garrod first pointed out that many human diseases related to recessive traits are due to metabolic defects[7]. However, only in 1941 did the experiments by Beadle and Tatum on Neurospora crassa allow the generalization stating "one gene, one enzyme"[8], which, 15 years later, became a less specific "one gene, one polypeptide" $[9,10]$. The discovery of the structure of the double helix[11] and the identification of the genetic code[12,13] transformed the definition of "gene" as a "transcribed code", and it was rapidly found that not all genes have proteins as their final output; for example, the genes encoding ribosomal and transfer RNAs are clearly of a different type. Recently, the Sequence Ontology Consortium provided the following definition of gene: "a locatable region of genomic sequence, corresponding to a unit of inheritance, which is associated with regulatory regions, transcribed regions and/or other functional sequence regions" $[3,4]$. This definition hints at two considerations: (1) especially in the first part, it closely resembles the original definition with the modification introduced by Morgan's studies, indicating that it is difficult to identify a gene by simply looking at the DNA sequence - indeed, although less accurate, a "locatable unit of inheritance" is still a good definition for "gene"; (2) the definition of "gene" is much wider, including functional sequences that do not necessarily include protein-coding sequences and that are not necessarily transcribed. For example, it is possible to include in the cited definition regions of DNA that are important per se (e.g., telomeres, centromeres), even when the DNA sequence is highly variable (like it happens for the centromeres), which are not transcribed, but have crucial functions in genome stability.

The Y chromosome of Drosophila melanogaster accounts for $40 \mathrm{Mb}$ of DNA[14,15], but contains only a few protein-coding sequences (to date 13 genes, one of which is in multiple copies) and two RNAcoding genes (i.e., the nucleolar organizer and the crystal locus[16]). Extremely long introns characterize some of these genes, but their presence alone is insufficient to explain the DNA content of this chromosome or the reason of their length. So the role of the majority of the heterochromatic regions contained in the $\mathrm{Y}$ chromosome is still to be elucidated. Moreover, most animal $\mathrm{Y}$ chromosomes are alike, e.g., (1) they are predominantly heterochromatic, (2) they do not possess a number of proteincoding genes comparable to similarly sized autosomes from the same organism, and (3) they are enriched in low-complexity DNA sequences. Therefore, it is likely that this kind of DNA plays some role and is not clusterized there just by chance, even if Y chromosomes may originate in several different ways[15]. Classic genetics was able to deal only with the few known sequences cited above, probably because most of the DNA content of the Y chromosome does not have a "classic" role. Even nowadays, the gene definition is a debated topic. This suggests that we should change the way we look at, and consequently study, these sequences. The Y chromosome is almost certainly not just a collection of a few genes interspersed in "junk DNA", but a chromosome that is important per se, whose presence alone (in some cases independently of the housed genes) may influence the behavior of many other genes located elsewhere in the genome in a continuous way. Also, the evolutionary role of this chromosome is important, especially in the creation of species-specific barriers and as a molecular clock for the studies of divergent speciation. In this perspective, D. melanogaster is once again a suitable model organism for the evolutionary and functional study of this type of DNA. 


\section{ON THE ORIGIN OF Y CHROMOSOMES AND THEIR ROLE IN SPECIATION}

It is generally accepted that the sex chromosomes of most animals arose from a couple of homologous autosomes after the acquisition of a dominant sex determination gene[17,18] and that the Y chromosome is the result of the degeneration of one of them[19,20,21]. Its degeneration would be a consequence of its lack of recombination with the $\mathrm{X}[22,23,24,25]$. It is possible that this nonselective situation favors the maintenance of repetitive DNA[26], although 40 years ago, a theory was proposed for a possible functional role of this type of sequence[27]. Interestingly, this theory was later supported by new studies on the mouse B2 transcript involved in heat-shock-induced transcription inhibition[28,29]. In general, the Y chromosome of most animals shows two features: (1) it harbors and accumulates by various means, mainly transposition and chromosome translocations, genes involved in male fertility[30]; and (2) most of its genes tend to degenerate rapidly, so that only a few of them remain functional[31]. Nonetheless, at least to some extent, pseudogenes also seem to evolve under functional restriction, so that they may gain new functions during evolution[32,33]. The evolution of the Y chromosome can be very fast, as recently reported for D. miranda[34]. This model system is particularly suitable for studies of this kind. Approximately 1 million years ago, an autosome of this fly fused to the Y chromosome[35], forming a socalled "neo-Y". The nonfused homologue is present in one copy in males and in two copies in females, and for this reason it is called "neo-X". Since in these flies, as in D. melanogaster, males completely lack meiotic recombination, and since the neo- $\mathrm{Y}$ is transmitted only from fathers to sons, the neo- $\mathrm{X}$ and neo-Y are completely unable to exchange genetic information by crossing over. A similar event probably also occurred for the human $\mathrm{Y}$ chromosome around 100 million years ago[36]. Comparative molecular analysis of the neo-sex chromosomes of $D$. miranda shows that transposable element insertions are relatively rare in the neo-X $(<1 \%)$ and far more abundant in the neo-Y, for which about $20 \%$ of the chromosomal DNA is either a transposon or is transposon derived. Moreover, indirect evidences suggest that overall repetitive sequences, including satellite DNA, might account for up to $50 \%$ of the neo-Y chromosomal DNA in D. miranda[34]. Finally, the same study underlines that almost half of the genes on the neo-Y accumulated mutations, such as early stop codons or frameshifts, which impair their function at the protein level. Nonetheless, functional genes on the neo-Y are still present, but seem to evolve more slowly than the average, and this is also true for their homologues on the neo-X. Transposons might play a role in gene regulation in the $\mathrm{Y}$ chromosome as well, being able to silence gene expression locally[34]. In D. melanogaster, the accumulation of male-related genes on the $\mathrm{Y}$ has been reported, but differently from Homo sapiens, the homologous genes are located on the autosomes, not on the X[15]. Even more striking is the discovery that $\mathrm{Y}$ chromosomes from closely related drosophilids may be very different[15,37], thus leading some authors to define the Y chromosome as "a chromosome that regularly segregates from the X chromosome, irrespective of its origin"[15]. This suggests two considerations: (1) although all $\mathrm{Y}$ chromosomes seem to evolve similarly in many organisms once they have been established, their origin may be very different even in the same taxon[15,38], being derived either from a couple of autosomes or from some B chromosome, or from both[14,15,39,40]; (2) the Y chromosome patroclinous inheritance favors the accumulation of genes and functions related to male fertility whatever chromosome they originally came from - so that these genes are under evolutionary pressure like genes on recombining chromosomes. Notably, this accumulation is relatively fast, being $\sim 11$ times higher than the gene loss due to spontaneous mutations and probably accounts for the different gene complement of the Y chromosomes of various drosophilids[15,37].

Among the genes mapping in the $\mathrm{Y}$ chromosome, it is possible to find loci involved in reproductive isolation and, therefore, this chromosome also exerts a role in this phenomenon. Indeed, it has been demonstrated that hybrid male sterility is the major cause of lethality or sterility in crosses between different species. In particular, the genes involved in this event are at least ten times more numerous than those causing similar phenotypes in females[41,42,43,44] and this process is also evolutionarily very fast[41,45,46]. One of these genes, called Odysseus[47,48] has been recently reported as one of the main causes of male sterility in crosses between $D$. mauritiana and $D$. simulans, causing extensive constitutive heterochromatin decondensation in the Y chromosome of $D$. simulans[49]. Interestingly, this is not the only 
case in which heterochromatin is involved in hybrid sterility - a similar situation occurs in D. melanogaster for the Zhr locus[50,51], a satellite DNA located in the X heterochromatin which interferes in cis with the normal chromosome segregation[52] and with the heterochromatin binding protein $\operatorname{Lhr}[53]$.

\section{THE Y CHROMOSOME OF D. MELANOGASTER AND ITS GENETICS}

The nature of the Y chromosome has been an obstacle for its genetic analysis. Morgan demonstrated that this chromosome does not contain the same genes of its "homologue" (the $\mathrm{X}$ ) and it is impossible to map genes on it because it shows almost no recombination[54,55,56,57,58,59,60]. Also, mutagenesis studies failed; the Y chromosome does not contain genes whose function is evident in phenotypic traits and it does not harbor genes essential for viability. Indeed, aneuploid flies lacking it, with an X0 karyotype, are viable males[61,62] and only show a weak thinning and shortening of bristles and sometimes etching of the abdomen. We now know that these visible phenotypes are mainly due to the reduced number of rRNA-coding genes, which are located in the constitutive heterochromatin of both sex chromosomes[54,63,64,65,66,67,68,69] and are responsible for X-Y pairing during the male meiosis[70]. The Y chromosome was also demonstrated to be genetically inert[71] and entirely heterochromatic[72,73,74]. It comprehends approximately $12 \%$ of the male genome[75] for a total of $\sim 40$ $\mathrm{Mb}$ of DNA[14,15], and is composed mainly of transposons and repetitive, simple sequence DNA (Fig. 1 and references therein). However, a clear phenotype is associated with the Y chromosome: X0 males are completely sterile and the factors responsible for this trait are located on both chromosomal arms[54]. Sex determination and dosage compensation in D. melanogaster are different from mammals in general and H. sapiens in particular[90]; in fact, in the fruit fly, they are both driven by the ratio between the $\mathrm{X}$ chromosome(s) and the autosomes. Thus, both XY and X0 flies are males (but the latter are sterile), and both XX and XX-Y flies are females (in both cases, they are fertile). Consequently, XX-Y females may be crossed to obtain offspring with supernumerary Y chromosomes, such as XY-Y (fertile) males, which in turn may be crossed as well to obtain other, more complex karyotypes. This allows the analysis of the influence of the $\mathrm{Y}$ chromosome in a variety of genetic backgrounds. The analysis of the hyperploidy of the $\mathrm{Y}$ chromosome in either males or females indeed showed some unexpected, yet very interesting features. The $\mathrm{Y}$ chromosome exerts an epigenetic effect in the PEV (position effect variegation) phenomenon[91] in the way that an extra Y in the karyotype (XX-Y females and XY-Y males) suppresses the variegation[92,93,94,95,96,97]. On the contrary, a missing $Y$ (X0 males) enhances PEV[98]. Hyperploid XX-Y females also show a modification of the nucleotide pool balance inside unfertilized eggs, although none of the genes mapped on the $\mathrm{Y}$ chromosome to date seem to be involved in nucleotide metabolism. In particular, eggs show a decrease of thymine and a contemporary increase of cytosine, although the total amount of pyrimidines remains the same if compared to eggs produced by XX females; instead, the overall content of purines is doubled, mainly due to adenine increase[99,100]. Further, raising the number of $\mathrm{Y}$ chromosomes causes new phenotypes to occur: (1) mottling of the eyes in both sexes[101] and male sterility[101,102] for two extra Y chromosomes (i.e., XX-Y-Y females and XY-Y-Y males); (2) perhaps female sterility and male lethality for three extra Y chromosomes (XX-Y-Y-Y females and XY-Y-Y-Y males)[103,104].

\section{MAPPING AND IDENTIFICATION OF GENES IN THE Y CHROMOSOME OF $D$. MELANOGASTER}

In order to better understand the role of the sex chromosome in male fertility, Brosseau performed an extensive genetic analysis of Y chromosome rearrangements that allowed him to localize seven loci, five on the long and two on the short arm[81]. They were named $k l-1$ to $k l-5$ on the long arm, and $k s-1$ to $k s-2$ on the short arm. However, subsequent studies did not allow the identification of the $k l-4$ gene, so for many years it was assumed that only six genes - or, better, "fertility factors" - were located on 


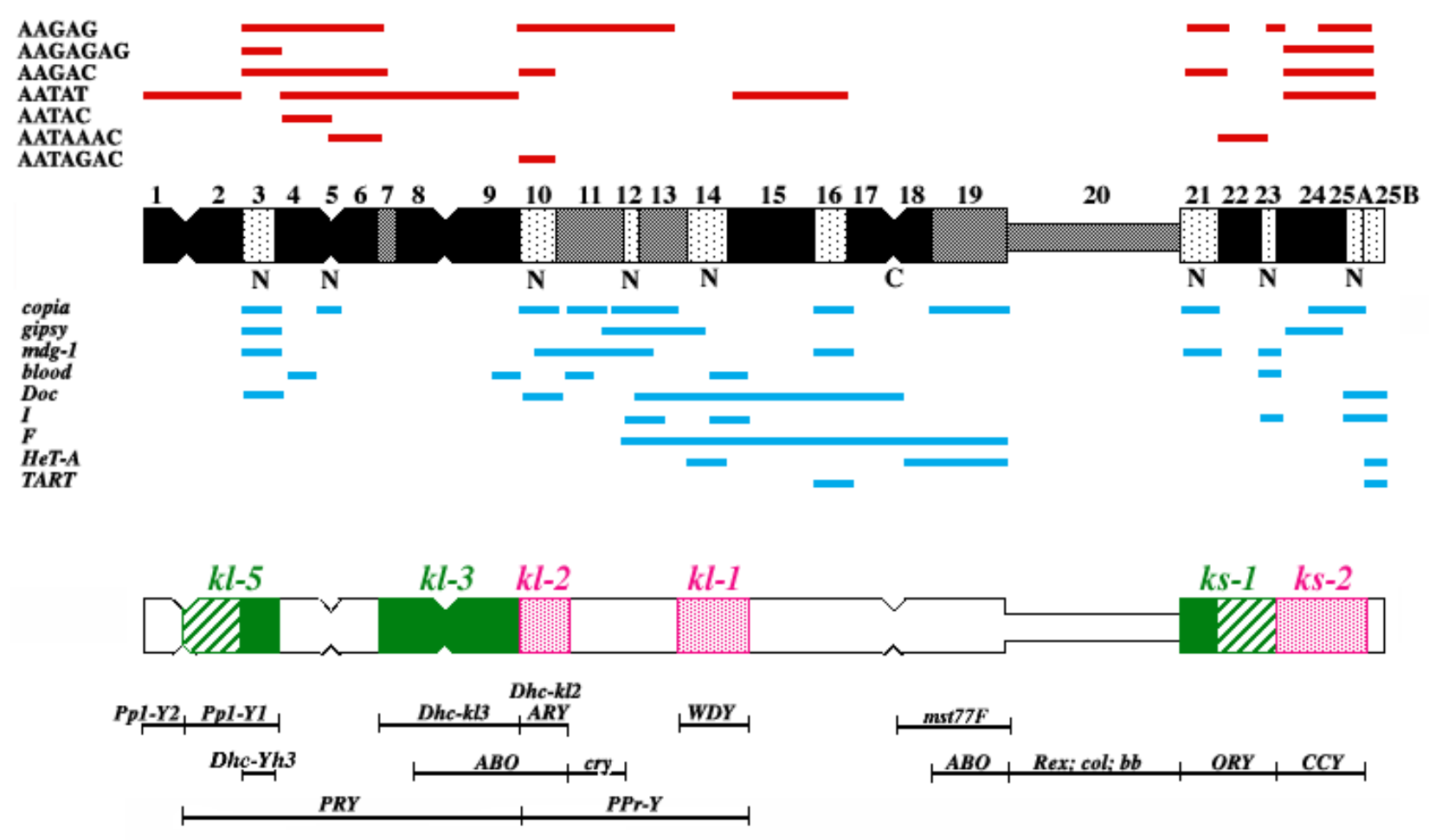

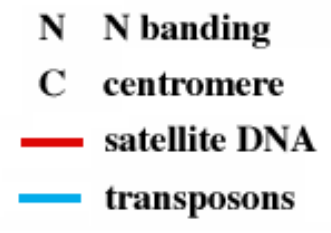

$\mathbf{N}$ banding

C centromere

transposons

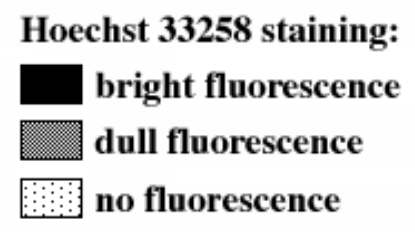

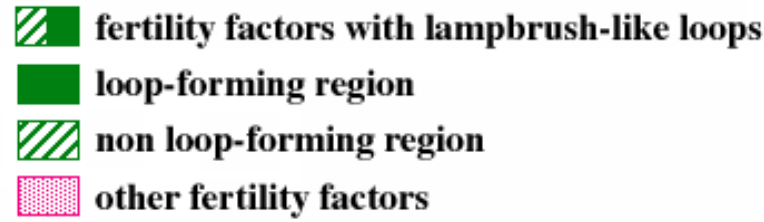

FIGURE 1. Schematic representation of the Y chromosome of D. melanogaster. All parts of the scheme are aligned with the Hoechst 33258 banding. From top to bottom: cytological localization of satellite DNAs[76,77]; Y chromosome diagram showing N banding and Hoechst 33258 banding[75,78]; cytological localization of transposable elements[79,80]; Y chromosome diagram showing the cytological localization and organization of six[78] of the fertility factors described by Brosseau[81]; other genetic elements mapping on the Y chromosome[78,82,83,84,85,86,87]. (Note on the image: this picture is reprinted from Piergentili and Mencarelli[88] and modified according to Vibranovski et al.[86]; no data are available to date about the location of the fdy gene[89].)

it[78,81,105,106,107]. Their fertility function is exerted mainly during the development and maturation of primary spermatocytes $[108,109]$ and their absence or malfunction causes several problems during spermatogenesis (Table 1), finally leading to the development of immotile sperms.

The analysis of $\mathrm{Y}$ chromosome rearrangements demonstrated that each fertility factor spans $\sim 4,000$ $\mathrm{kb}$ of DNA, so it is more than 100 times larger than the average eukaryotic locus. Three of these fertility factors - namely, $k l-3, k l-5$, and $k s-1$ - are responsible for the formation of giant lampbrush-like loops, which recall the lampbrush chromosomes of amphibian oocytes, from which they also take their name[107]. These "Y loops" are the cytological manifestation of genetic activation of the Y chromosome during the primary spermatocyte development[110] and are a conserved feature of many drosophilids[111]. Interestingly, during the meiotic metaphases, the sister chromatids of the Y chromosome are separated, which is cytological evidence of their previous activity; instead, in all other tissues, the sister chromatids are close to each other and indistinguishable in mitotic metaphases because of the "stickiness" of the heterochromatin (Fig. 2). The kl-3 loop at its maximum extension appears as a thin filament with no free ends when analyzed at the phase contrast microscope, while the other two loops have a more dense aspect[110], although they probably have a thread-like organization as well[88,112]. 
TABLE 1

Fertility Factors Missing from the Y Chromosome and Corresponding Abnormal Phenotypes in D. melanogaster Spermatogenesis

\begin{tabular}{|c|c|c|}
\hline $\begin{array}{l}\text { Missing } \\
\text { Fertility } \\
\text { Factor }\end{array}$ & $\begin{array}{l}\text { Premeiotic } \\
\text { Defects }\end{array}$ & Postmeiotic Defects \\
\hline$k l-1$ & None described & $\begin{array}{l}\text { Wrong nebenkern/axoneme alignment; missing tubular structures inside cyst } \\
\text { lumen; wrong coiling of sperm tails; wrong spermatid orientation; missing } \\
\text { spermatids inside the cyst; immotile sperm tails }\end{array}$ \\
\hline$k l-2$ & None described & One high-molecular-weight polypeptide missing ( $350 \mathrm{kD})$ \\
\hline$k l-3$ & kl-3 loop absent & $\begin{array}{l}\text { Absence of external dynein arms from axoneme peripheral doublets; one } \\
\text { high-molecular-weight polypeptide missing }(\sim 300 \mathrm{kD}) \text {; wrong } \\
\text { nebenkern/axoneme alignment }\end{array}$ \\
\hline$k l-5$ & $k l-5$ loop absent & $\begin{array}{l}\text { Absence of external dynein arms from axoneme peripheral doublets; one } \\
\text { high-molecular-weight polypeptide missing }(\sim 300 \mathrm{kD}) \text {; wrong } \\
\text { individualization of spermatids; nebenkern without axonemes and vice } \\
\text { versa; partial cytoplasm retention inside sperm heads; immotile sperm tails }\end{array}$ \\
\hline$k s-1$ & $\begin{array}{l}\text { ks-1 loop } \\
\text { absent }\end{array}$ & $\begin{array}{l}\text { Missing tubular structures inside cyst lumen; wrong nebenkern/axoneme } \\
\text { alignment; similar, but stronger, spermatid defects compared to kl-1; sperm } \\
\text { tail coiling apparently normal, but with immotile sperm tails }\end{array}$ \\
\hline ks-2 & None described & $\begin{array}{l}\text { Wrong nebenkern/axoneme alignment; failures in the individualization of } \\
\text { spermatozoa; nebenkern without axonemes and vice versa }\end{array}$ \\
\hline
\end{tabular}
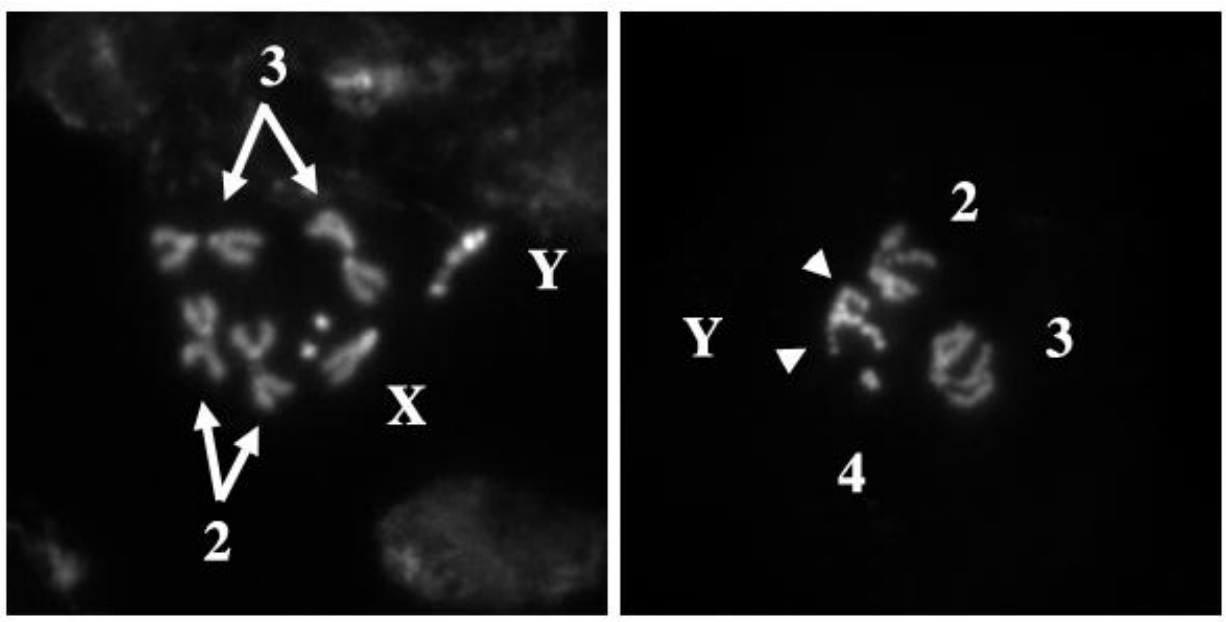

FIGURE 2. Comparison between mitotic (left) and meiotic (right) $\mathrm{Y}$ chromosome in the male germ line of D. melanogaster, as they appear with the DAPI dye. Numbers indicate chromosomes (on the left image, chromosomes number 4 are the white dots next to the $\mathrm{X}$ chromosome). (Left) mitotic metaphase from a larval neuroblast. Note that the entirely heterochromatic Y chromosome shows attached sister chromatids as a consequence of the "stickiness" of the heterochromatin. (Right) A meiotic metaphase II. Note that the Y chromosome, recognizable by chromosomal banding, shows separated sister chromatids (arrowheads) as a remnant of its genetic activation during the primary spermatocyte development. (Note on the image: original microphotographs of the author.)

The development of "Y loops" is temporally controlled: the $k l-3$ loop is the last to form, and all loops rapidly disintegrate during the late meiotic prophase I[110], probably as a consequence of chromosome condensation. These loops are also characterized by their ability to bind large amounts of proteins; they are intensely stained by the Giemsa, Coomassie blue, and dansyl-chloride dyes[110]. Many bound 
proteins have been isolated and characterized, and antibodies have been raised against some of them[111,113,114,115,116,117,118,119,120,121,122,123,124,125]. It is interesting to note that none of these proteins is encoded by genes mapping on the Y. Also, their function is highly variable - DNA- and RNA-interacting proteins, testis-specific proteins accumulated either in the nucleus or in the sperm tail. Other than the six fertility factors and the nucleolar organizer, more functions were assigned to the $\mathrm{Y}$ chromosome during the years (Fig. 1 and Table 2)[78,82,83] but, as expected, the genetic analysis of these genes has been very difficult. The discovery of new genes had a stop until the completion of the $D$. melanogaster genome sequence analysis[126] offered new tools to solve this problem. Computer-based approaches[127] allowed the discovery of more protein-coding sequences on the Y[84,85,86,87,89], thus increasing the number of "classical" genes (either protein- or RNA-coding) to at least 15[14,15] (Fig. 1 and Table 2). Notably, many of these genes have at least one autosomal, but not an X-linked, counterpart, so it is not clear yet if their activity, if any, is necessary or just redundant[15,84,85,86,87]. It is worth underlining that all six "fertility factors" described in 1960 are now correlated to the presence of at least one protein-coding sequence (Fig. 1 and Table 2), thus strongly suggesting that the impaired male fertility of the translocated Y chromosomes studied by Brosseau is due to the interruption of one of these genes. However, for some of these proteins, an essential role in male fertility was excluded $[84,85,86,87]$ either for the presence of mutations or for the presence of an homologous counterpart, or even because every fertility factor most likely contains only one essential protein-coding gene[105]. Moreover, the reason why only three of these loci have a visible phenotype inside primary spermatocyte nuclei (Y loops) and the others do not is still a topic of discussion (see the end of the next section).

\section{ROLE OF THE Y CHROMOSOME IN THE HEAT-INDUCED MALE STERILITY PHENOMENON}

More than 80 years ago, it was first demonstrated that flies reared at high temperatures do not reproduce because of a reversible sterilization of males[128,129]. For D. melanogaster, this occurs at $\sim 30^{\circ} \mathrm{C}$; at $32^{\circ} \mathrm{C}$, flies die at the pupal stage[130]. Further studies demonstrated that this is a general feature of most, if not all, drosophilids[131,132]. The difference between the temperatures at which lethality or viability/fertility occurs is (1) usually very small (no more than two degrees), (2) species and population specific, and (3) correlated to the average temperature at which wild flies usually live[132]. It is possible to increase the temperature at which flies become sterile by artificial selection[133,134,135]. This selection is possible within a limited number of generations, indicating that this process is very fast by the evolutionary standpoint. Of great interest is the finding that the Y chromosome is directly involved in heat resistance and accounts for at least $50 \%$ of the variability[132]. Introducing a Y chromosome of a tropical population in a temperate population by crosses has the effect to increase the heat resistance of the temperate group; on the contrary, the reverse crosses lower the heat resistance of tropical groups[135]. As previously noted, the heatinduced sterility is a reversible phenomenon; bringing males back to the permissive temperature allows the recovery of male fertility in a variable number of days. This number depends on different variables: (1) the time spent at the nonpermissive temperature (the more time spent, the more time needed for the recovery), (2) the temperature itself (recovery after exposure to $31.5^{\circ} \mathrm{C}$ requires more time than a time-equivalent exposure to $31^{\circ} \mathrm{C}$ ), and (3) the origin, tropical or temperate, of the population considered (tropical populations recover faster)[132,135,136,137,138]. The introduction of an external Y chromosome allows varying significantly the recovery time in all conditions[135]. This clearly indicates that Y-dependent, temperature-related male fitness is a target for natural selection. Moreover, the high speed of evolution of these traits fits quite well with the high variability of noncoding sequences inside the Y chromosome. At the cytological level, male infertility is due to a series of abnormalities in the germ line, such as shorter cyst length and anomalous cyst elongation; spermatid death rate, and, consequently, number of mature sperm heads; and level of chromatin condensation inside sperm heads[132,135]. Interestingly, some of these features are also common in mutant lines having the rearranged Y chromosomes described by Brosseau[81] and missing some of the fertility factors (Table 1) [139]. 
TABLE 2

Summary of the "Locatable Units of Inheritance" Mapping on the Y Chromosome*

\begin{tabular}{|c|c|c|c|c|c|}
\hline $\begin{array}{l}\text { Unit } \\
\text { Name }\end{array}$ & Unit Type & Location & $\begin{array}{l}\text { No. of } \\
\text { Copies }\end{array}$ & Molecular Function & $\begin{array}{l}\text { Biological } \\
\text { Function }\end{array}$ \\
\hline Pp1-Y2 & Protein coding & h1 & 1 & $\begin{array}{l}\text { Serine/threonine } \\
\text { phosphatase }\end{array}$ & Unknown \\
\hline Pp1-Y1 & Protein coding & h2-h3 & 1 & $\begin{array}{l}\text { Serine/threonine } \\
\text { phosphatase }\end{array}$ & Unknown \\
\hline PRY & Protein coding & h2-h9 & 1 & Unknown & Unknown \\
\hline Dhc-Yh3 & Protein coding & h2-h3 & 1 & Dynein heavy chain & Sperm movement \\
\hline kl-5 loop & $\begin{array}{l}\text { Structural } \\
\text { element }\end{array}$ & h3 & 1 & Unknown & Triplex formation \\
\hline kl-3 loop & $\begin{array}{r}\text { Structural } \\
\text { element }\end{array}$ & h7-h9 & 1 & Unknown & Triplex formation \\
\hline Dhc-kl3 & Protein coding & h8 & 1 & Dynein heavy chain & Sperm movement \\
\hline $\mathrm{ABO}$ & Unknown & h10-h11 and h19 & 2 & Unknown & $\begin{array}{l}\text { Suppression of abo } \\
\text { mutation }\end{array}$ \\
\hline Dhc-kl2 & Protein coding & h10-h11 & 1 & Dynein heavy chain & Sperm movement \\
\hline ARY & Protein coding & h10 & 1 & Aldehyde reductase & Unknown \\
\hline cry/Su(Ste) & RNA coding & h11 & $\sim 80$ & Protein kinase regulator & $\begin{array}{l}\text { Suppression of Ste } \\
\text { gene }\end{array}$ \\
\hline Ppr-Y & Protein coding & h10-h14 & 1 & $\begin{array}{l}\text { Protein phosphatase type } \\
1 \text { regulator }\end{array}$ & Unknown \\
\hline WDY & Protein coding & h14 & 1 & Unknown & Unknown \\
\hline Centromere & $\begin{array}{r}\text { Structural } \\
\text { element }\end{array}$ & h17-h18 & 1 & Spindle interaction & $\begin{array}{r}\text { Chromosome } \\
\text { segregation }\end{array}$ \\
\hline Mst77F & Protein coding & h18-h19 & $16-20$ & Unknown & Unknown \\
\hline $\mathrm{bb} / \mathrm{col} / \mathrm{Rex}$ & RNA coding & h20 & $\sim 200$ & rDNA & $\begin{array}{l}\text { Protein } \\
\text { biosynthesis }\end{array}$ \\
\hline ks-1 loop & $\begin{array}{l}\text { Structural } \\
\text { element }\end{array}$ & h21 & 1 & Unknown & Unknown \\
\hline ORY & Protein coding & h21-h23 & 1 & Unknown & Unknown \\
\hline $\mathrm{CCY}$ & Protein coding & h24-h25A & 1 & Unknown & Unknown \\
\hline Telomere & $\begin{array}{l}\text { Structural } \\
\text { element }\end{array}$ & $\mathrm{h} 1$ and h25B & 2 & $\begin{array}{l}\text { Chromosome ends } \\
\text { protection }\end{array}$ & $\begin{array}{r}\text { Chromosome } \\
\text { segregation }\end{array}$ \\
\hline fdy & Protein coding & nd & 1 & Unknown & Unknown \\
\hline
\end{tabular}

* According to the text, structural functions are also listed. Data partly collected from FlyBase (URL: http://www.flybase.org) Release FB2010_05.

By performing time measurements for fertility recovery and knowing that at $25^{\circ} \mathrm{C}$ the spermatogenesis lasts approximately 10 days, it was found that in the male germ line, the most heat-sensitive cells are primary spermatocytes[140], which are genetically characterized by the Y chromosome activation (Fig. 2) and cytologically distinguished by the presence of the Y loops. An analysis of the satellite sequences harbored in these chromosomal regions (Fig. 1) suggests that at least some of them might organize an atypical three-dimensional conformation known as "triplex"[141]. Indeed, the immunostaining of primary spermatocyte nuclei with antitriplex antibodies[142,143,144,145,146,147] revealed that at least two of them, $k l-3$ and $k l-5$, are specifically decorated[88]. A study of testes from males reared at the nonpermissive temperature of $31 \pm 0.5^{\circ} \mathrm{C}$ showed that, although apparently normal, the $\mathrm{Y}$ loops are no more immunostained by the antitriplex antibodies, suggesting that these structures are heat sensitive[88]. 
The contemporary absence of triplex staining and of two high-molecular-weight polypeptides associated with the presence[148] and with normal development[149] of $k l-3$ and $k l-5$ loops for the first time allowed establishment of a correlation among $\mathrm{Y}$ chromosome satellite DNA, unusual DNA structures, heat sensitivity, and an abnormal biochemical pattern of proteins involved in the normal sperm tail development[148] and, consequently, in the male fertility. Another set of experiments aimed at the isolation of autosomal mutations affecting the size and/or development of Y loops further supports the possibility that these regions might fulfill a structural role before meiosis. Ceprani and coworkers[150] isolated two mutations, named dolly-1 and dolly-2, whose cytological phenotype is not a reduction or a someway-altered development of the loops, but is their splitting into two identical halves. Since each loop is formed equally by the two sister chromatids (indeed, there is no reason to believe the contrary), it has been suggested that the two halves are the cytological manifestation of some missing chromatin structure at the ultrastructural and/or molecular level, which terminally results in the loop splitting.

Since no other defects are evident in the germ line of mutant flies except immotile sperm tails, the conclusion drawn is that there is a relationship between the ultrastructural organization of the Y loops and the normal development of the sperm tail. The presence of duplicated loops also allows the exclusion of the missing transcription of the open reading frames inside these loci as a cause of sperm immobility, since this part of the Y chromosome is still cytologically - and, probably, genetically - active. As noted before, several proteins encoded by the autosomes localize on the Y loops, so it is likely that these structures are not just the cytological manifestation of the transcription of unusually long genes[151,152,153]. Indeed, these structures may also be places for docking or storing proteins that are ready since before the meiosis, but that will exert their function much later, during the spermiogenesis. While it is not yet clear if this localization also implies some post-translational modification, it is noteworthy that some of the mutant lines with a reduced or absent $k l-3$ loop still produce the highmolecular-weight polypeptides described by Goldstein and collaborators[148], although these proteins are unstable and rapidly degraded[149]. This degradation is not an intrinsic feature of such proteins, since they are still visible in testes dissected and kept in physiological solution at $32 \pm 0.5^{\circ} \mathrm{C}$ for $2 \mathrm{~h}$ before analysis[88]. Since even reduced loops of mutant flies are still able to bind proteins and are decorated by specific antibodies[149,150], it is likely that this issue is not qualitative, but quantitative. This observation further supports the idea that the open reading frames hosted on the Y chromosome are only partially or not at all involved in the male sterility caused by the above-mentioned autosomal mutations.

\section{THE Y CHROMOSOME PLAYS A CENTRAL ROLE IN GENOME FUNCTION}

In their paper on the male sterility of flies at extreme temperatures, David and collaborators[132] hypothesize two ways to explain the correlation between viability and sterility thresholds. Either these two traits are independent, and for some reason under temperature-driven selection, or they share a genetic basis, indicating that genes with pleiotropic effects may influence both phenotypes. Recent data seem to suggest that the truth is somewhere in the middle. As reported previously, introducing a Y chromosome into a different genetic background may greatly influence the heat resistance. This means that, to a great extent, the $\mathrm{Y}$ chromosome alone can influence these traits, being at least partially independent from the other chromosomes. Nonetheless, the genetic background is important as well. The analysis of a large number of male sterile mutations characterized by defective Y loops[150] demonstrates that more than half of the loci identified influence both the normal behavior of Y loops and some aspects of meiosis. This finding indicates that these genes induce pleiotropic, deleterious defects in the male germ line upon mutation. It should also be remembered that several autosome-encoded proteins localize on the Y loops before the meiotic prophase I. Taken together, these data suggest that, at least in the male germ line, the $\mathrm{Y}$ chromosome is part of a network of genetic and biochemical interactions. These multiple connections had been partially highlighted by some works illustrating the role of the Y chromosome in sperm competition[84] and its strong role on general male fitness[154], as well as in sex ratio distortion[155,156] and in fly behavior[157,158]. Recently, Lemos and coworkers[159] demonstrated that 
the $\mathrm{Y}$ chromosome polymorphism might deeply influence the activity of many genes (estimated in the range 100-1,000) located on other chromosomes[160,161 for comments], other than on itself. Interestingly, the most abundant genes in the list are those connected to male fertility and influenced by heat stresses, and many of these are important for sperm development. Among these over-represented are genes influencing the mitochondria. This is not surprising; very long sperm tails characterize drosophilids. In D. melanogaster, spermatozoa are $1.8 \mathrm{~mm}$ long (the fly being approximately $5 \mathrm{~mm}$ long); in D. hydei and D. bifurca, they are $23 \mathrm{~mm}$ and almost $60 \mathrm{~mm}$ long, respectively[109,111,162,163,164]. During spermatogenesis, after meiotic divisions, mitochondria are organized in spherical structures known as "nebenkern". These structures elongate and divide into two symmetric halves between which the sperm axoneme is built; mitochondria then supply the necessary energy for the sperm tail movement. Because the size of the sperm tails is huge, a gene influencing the mitochondrial function will likely influence male fertility. Another feature resulting from the same study[159] is that the affected genes are more dynamic from an evolutionary point of view, since their expression is more polymorphic. It has been noted that the few functional protein-coding genes on the $\mathrm{Y}$ chromosome undergo a stronger than average natural selection as time passes[34], and that the number of gene gains is higher than gene losses[15,37]. Then, probably, the destiny of the $\mathrm{Y}$ chromosome is not disappearing, as hypothesized[165,166], and, most likely, its degeneration will stop. This evolution would ultimately lead to the specialization of the $\mathrm{Y}$ chromosome as a major modulator, but not as an on/off switch, of gene expression in males. This will possibly result in continuous rather than discrete effects on gene expression[160]. Noteworthy, this effect is exactly as it has been found for heat resistance and for Y loops behavior (i.e., mutations with reduced, but not absent loops). The method used by Lemos is basically the same as that of David (i.e., introducing a "new" Y chromosome inside a different genetic background), and the measurements were performed using the microarray technology. Also in this case, a tropical Y chromosome introduced into a temperate genetic background is able to induce misexpression of several genes, some of them being over- and others underexpressed according to the genetic crosses performed.

Another recent progress in the analysis of the genome-wide influence of the Y chromosome was the discovery that this genetic element may influence dosage compensation by imprinting[167]. The imprinting phenomenon had been previously described in the fruit fly $[168,169,170]$, but in those cases, the $\mathrm{Y}$ chromosome imprinted genes physically located on itself, irrespective of their origin (either transposed or translocated after chromosomal rearrangements). In many cases, the expression of a reporter transgene (yellow, white, or both) transposed into the Y chromosome is different if the Y comes either from XY males or from XX-Y females. Similarly, a yellow gene (normally X linked) moved onto the $\mathrm{Y}$ chromosome by an $\mathrm{X}-\mathrm{Y}$ translocation may be influenced in its expression in a similar way, even if yellow is de facto inside a euchromatic region[170], thus indicating that the $\mathrm{Y}$ imprinting can influence non-Y sequences. The work of Menon and Meller[167] pushes this phenomenon farther. Dosage compensation in D. melanogaster requires the presence of $\mathrm{X}$ - and autosome-encoded proteins, whose ratio determines the maleness or femaleness of the embryo[90]. So, apparently, the Y chromosome is not required for this choice. Once the sex is established, males compensate their one-copy X-linked genes by overexpressing them, compared to females[171]. Dosage compensation is achieved by the MSL complex, which includes also two noncoding RNAs (roX1 and roX2) that are encoded by the X chromosome[172]. Only mutation of both $r o X$ genes causes male lethality, which indicates that these genes are redundant[173]. The authors found that males carrying a paternally derived roX1 roX2 double-mutant X chromosome and a maternally derived $\mathrm{Y}$ chromosome show a dramatically increased survival when compared to males having the same sex chromosomes inherited in the natural way, and that "this effect can be attributed solely to the presence, and parent of origin, of the Y chromosome"[167]. Indeed, the absence of a Y chromosome (X0 males) confers an intermediate survival, which implies that the mere "presence" of this chromosome is as important as its content. 


\section{OF FLIES AND MEN - DIFFERENT YET SIMILAR Y CHROMOSOMES}

A brief list of similarities between the $\mathrm{Y}$ chromosomes of flies and humans is reported in Table 3 . The $\mathrm{Y}$ chromosome of $\mathrm{H}$. sapiens is $60 \mathrm{Mb}$ long and has a long block of constitutive heterochromatin on the long arm (Yq), spanning $40 \mathrm{Mb}[174]$. There are two pseudoautosomal regions at the tips of the chromosome, accounting for about $3 \mathrm{Mb}$ of DNA. Only these regions are able to pair and recombine with homologous sequences located on the $\mathrm{X}$ chromosome, so that $95 \%$ of the DNA mapping on the $\mathrm{Y}$ is male specific[21]. Instead, the male-specific region (MSY) is able to undergo intrachromosomal recombination, a mechanism probably involved both in its self-maintenance[175] and in the observed high Y chromosome mutation rate and structural polymorphism[176]. The euchromatic portion of the male-specific region essentially contains three types of sequences: $\mathrm{X}$ transposed, $\mathrm{X}$ degenerated, and amplicons[21]. X-transposed sequences are 99\% identical to DNA sequences mapping in Xq21 and are probably the result of massive X-to-Y transposition that occurred about 3-4 million years ago[177,178,179]. Interestingly, although these regions account for a total of $3.4 \mathrm{Mb}$ of DNA, only two protein-coding genes map on them, while a high density of interspersed and repeated elements is present[21]. X-degenerated sequences contain single-copy genes or pseudogenes that are homologous to 27 different X-linked genes. Out of them, only 14 are apparently functional; these genes have an X-linked homologue coding for slightly different isoforms[21] and are ubiquitously expressed in 12 cases. Finally, amplicons are repeated, Y-specific sequences spanning a total of $10.2 \mathrm{Mb}$. They contain most of the genes exclusively expressed in male testes and their organization can be either a direct or an inverted repeat. Amplicons are also the units of more complex chromatin structures called palindromes[180]. Most of the mutations and microdeletions causing male infertility map inside the euchromatic portion of the $\mathrm{Y}$ chromosome[181,182,183]; in particular, only $6 \%$ of the sterility-causing microdeletions map outside the "azoospermia factor" (AZF) regions[184]. However, the lack of one or more genes is sometimes insufficient to explain the Y-related male sterility, also because of the redundancy of many sequences. In a recent paper[185], the authors hypothesize that the sterility associated with some microdeletions might be due not just to the absence of a gene, but to the alteration of the chromatin structure, thus impairing the premeiotic X-Y chiasma formation. Moreover, other studies demonstrated that the same microdeletion may or may not be the primary cause of infertility[186], indicating that the genetic background may influence the genetic behavior of the Y chromosome[183]. It is interesting to underline that the majority of the human Y chromosome, i.e., the heterochromatic portion, has not been investigated yet for the presence of "functions" related to male fertility, because of the absence of well-characterized chromosome rearrangements, the low complexity of the harbored sequences, and the apparent lack of any protein-coding sequence. However, it has been reported that the subtotal deletion of the Y chromosome is linked at least to morphophysiological variability[187, cited in 183].

The Y chromosomes of flies and humans are clearly different, yet they share interesting features (Table 3). If we look at the relatively few molecular data available, the similarity is even more interesting. For example, the RNA-binding "deleted in azoospermia" (DAZ) protein, encoded by the human Y chromosome and responsible for a high number of Y-related male infertility clinical cases, has a homologue in the fruit fly called Boule. Interestingly, antibodies raised against Boule demonstrated that this protein moves to the $k s-1$ loop before D. melanogaster male meiosis, indicating that it is able to specifically recognize such structures[121]. Is it possible that the human Y chromosome forms loop-like structures as well? Are there chances that this protein also recognizes similar structures in $H$. sapiens? May the absence of such structures in humans, if they occur, or the inability of a mutated DAZ protein to recognize them, impair male fertility, as it happens in fruit flies? Is it possible that triplexes also have a role in human spermiogenesis? Can we establish a correlation between the morphophysiological variability described in humans and that described in flies for large alterations in the total amount of Yrelated constitutive heterochromatin? A closer look at the structure and function of the heterochromatic portion of the human $\mathrm{Y}$ chromosome may possibly lead to new, exciting discoveries for the widespread problem of male infertility in humans. 
TABLE 3

Similarities between Fly and Human Y Chromosomes*

\begin{tabular}{lcc}
\hline Feature & Human & Fruit Fly \\
\hline Portion lacking cross-over & $95 \%$ & $100 \%$ \\
Proportion of heterochromatin & $\sim 65 \%$ & $100 \%$ \\
Length of heterochromatic sequences & $\sim 40 \mathrm{Mb}$ & $\sim 40 \mathrm{Mb}$ \\
Genes with male-specific expression & Yes & Yes \\
Presence of active transposable elements & Yes & Yes \\
Presence of satellite DNA & Yes & Yes \\
Number of protein-coding genes & 60 & 13 \\
rRNA genes & 7 & $\sim 200$ \\
Other RNA-coding genes & 37 & 1 \\
X0 individuals & Viable/sterile & Viable/sterile \\
Evolutionarily conserved proteins & Yes & Yes \\
\hline * Data about genes on the human Y chromosome were collected from
\end{tabular}

\section{CONCLUSION}

The study of the function of constitutive heterochromatin, although started several decades ago, is still in its early stages. For example, centromeres and telomeres are portions of the genome that harbor repetitive DNA sequences, for which a lot of interacting proteins have been described; yet a comprehensive model of function is missing. The situation for the Y chromosome is even worse. Many genetic aspects of the satellite DNA functions are elucidated, but in most cases, there is no molecular model at all to explain how heterochromatin exerts its role. Data collected to date allow us to draw some conclusions: (1) many, if not all, of the influenced characters show a continuous variation, indicating that the role of the $\mathrm{Y}$ chromosome is not an on/off switch, but a fine regulator of complex phenotypes; (2) the Y role is not exerted by the "classic" protein-coding genes that it contains since none of them, to date, has been directly related to these phenotypes; and (3) the Y chromosome is able to interact physically with a very large number of autosomal-encoded proteins, as has been demonstrated for the proteins loaded on the Y loops and for its role in PEV. Taken together, these data indicate that, at least in the male germ line, the Y chromosome is part of a network of genetic and biochemical interactions that only recently are beginning to be elucidated.

Most of these features can evolve very quickly, strongly suggesting that the main role is likely exerted by the noncoding sequences - transposable elements and simple-sequence satellite DNA. Instead, the few male-specific coding sequences, mostly involved in sperm tail formation and function, seem to be under stronger than average evolutionary pressure, mainly because they encode proteins that have specific roles in the male germ line. Interestingly, repetitive DNA sequences account for most chromosomal DNA and are a typical feature of all animal Y chromosomes. As a result, despite its lack of recombination and its patroclinous inheritance, the $\mathrm{Y}$ chromosome is still subject to natural selection. The discovery that in many cases the noncoding parts of the chromosome also have an important role suggests that this part of the chromatin might be under evolutionary pressure as well. However, it is clear that the forces acting on it and the way the evolution is exerted at the molecular level have to be very different - in this case, as stated before, we are talking about "genes" in the widest meaning. Repetitive DNA changes are essentially quantitative (i.e., are dose dependent) and not qualitative. Indeed, introducing point mutations in a stretch of satellite DNA 4,000 kb long (the size of the loop-forming fertility factors) is simply 
insignificant for the cell, so we may expect that this DNA mostly influences continuous characters exactly what was discovered during almost a century of studies. In this perspective, it is clear that this part of the genome cannot be studied using standard genetic or biochemical techniques; this explains why, although important, only a few results concerning how this chromosome influences cell metabolism were obtained by using these methods. It is conceivable that most of the phenotypes related to the Y chromosome are in some way connected to some high-level structures of the chromatin; in this resembling what happens for eukaryotic centromeres and telomeres. The recent discovery of triplestranded nucleic acids built by two loci on the Y chromosome shows another way this DNA can be organized at the three-dimensional level. This "unusual" structure is quite widespread among eukaryotes and since it is related to the presence of two of the Y loops, it is likely that it is a sort of molecular framework on which several proteins are loaded before meiosis. The discovery that this structure (1) may vary in a continuous way (i.e., mutants show variably reduced, but not absent loops), (2) is heat sensitive, and (3) influences the presence of proteins involved at least in male fertility, further supports the fact that noncoding DNA on this chromosome has a specific and important role in the biology of drosophilids. Heterochromatin is not just a collection of selfish genetic sequences whose only aim is to reproduce themselves from one generation to the next. The fact that these DNA are widely represented in all genomes strongly suggests that they should have a function; if not so, the speed of evolution of the $\mathrm{Y}$ chromosome would have caused them to disappear a long time ago.

\section{ACKNOWLEDGMENTS}

I would like to thank Tammy L. Moser (Duke University Medical Center, Duke University, Durham, NC) and Alessandro Porrello (Institute for Genome Sciences and Policy, Duke University, Durham, NC) for careful review of the manuscript.

\section{REFERENCES}

1. Johannsen, W. (1909) Elemente der exakten erblichkeitslehre. Gustav Fischer, Jena.

2. Mendel, G. (1866) Versuche über Pflanzen-Hybriden. Verh. Naturforsch. Vereines, Abhandlungen, Brünn 4, 3-47.

3. Pearson, H. (2006) Genetics: what is a gene? Nature 441, 398-401.

4. Gerstein, M.B., Bruce, C., Rozowsky, J.S., Zheng, D., Jiang Du, J., Korbel, J.O., Emanuelsson, O., Zhang, Z.D., Weissman, S., and Snyder, M. (2007) What is a gene, post-ENCODE? History and updated definition. Genome Res., 17, 669-681.

5. Pennisi, E. (2007) DNA study forces rethink of what it means to be a gene. Nature 316, 1556-1557.

6. $\quad$ Morgan, T.H., Sturtevant, A.H., Muller, H.J., and Bridges, C.B. (1915) The Mechanism of Mendelian Heredity. Henry Holt, New York.

7. Garrod, A.E. (1909) Inborn Errors of Metabolism. Oxford University Press, Oxford.

8. Beadle, G.W. and Tatum, E.L. (1941). Genetic control of biochemical reactions in Neurospora. Proc. Natl. Acad. Sci. U. S. A. 27, 499-506.

9. Ingram, V.M. (1956) A specific chemical difference between globins of normal and sickle-cell anemia hemoglobins. Nature 178, 792-794.

10. Ingram, V.M. (1957) Gene mutations in human hemoglobin: the chemical difference between normal and sickle hemoglobin. Nature 180, 326-328.

11. Watson, J.D. and Crick, F.H.C. (1953) Molecular structure of nucleic acids. A structure for deoxyribose nucleic acid. Nature 171, 737-738.

12. Nirenberg, M., Leder, P., Bernfield, M., Brimacombe, R., Trupin, J., Rottman, F., and O’Neal, C. (1965) RNA codewords and protein synthesis, VII. On the general nature of the RNA code. Proc. Natl. Acad. Sci. U. S. A. 53, 1161-1168.

13. Söll, D., Ohtsuka, E., Jones, D.S., Lohrmann, R., Hayatsu, H., Nishimura, S., and Khorana, H.G. (1965) Studies on polynucleotides, XLIX. Stimulation of the binding of aminoacyl-sRNA's to ribosomes by ribotrinucleotides and a survey of codon assignments for 20 amino acids. Proc. Natl. Acad. Sci. U. S. A. 54, 1378-1385.

14. Carvalho, A.B. (2002) Origin and evolution of the Drosophila Y chromosome. Curr. Opin. Genet. Dev. 12, $664-668$.

15. Carvalho, A.B., Koerich, L.B., and Clark, A.G. (2009) Origin and evolution of Y chromosomes: Drosophila tales. Trends Genet. 25, 270-277. 
16. Tritto, P., Specchia, V., Fanti, L., Berloco, M., D'Alessandro, R., Pimpinelli, S., Palumbo, G., and Bozzetti, M.P. (2003) Structure, regulation and evolution of the crystal-Stellate system of Drosophila. Genetica 117, $247-257$.

17. Charlesworth, D. and Charlesworth, B. (2005) Sex chromosomes: evolution of the weird and wonderful. Curr. Biol. 15, R129-131.

18. Steinemann, S. and Steinemann, M. (2005) Y chromosomes: born to be destroyed. Bioessays 27, $1076-1083$.

19. Rice, W.R. (1987) Genetic hitch-hiking and the evolution of reduced genetic activity of the Y sex chromosome. Genetics 116, 161-167.

20. Charlesworth, B. (1996) The evolution of chromosomal sex determination and dosage compensation. Curr. Biol. 6, 149-162.

21. Skaletsky, H., Kuroda-Kawaguchi, T., Minx, P.J., Cordum, H.S., Hillier, L., Brown, L.G., Repping, S., Pyntikova, T., Ali, J., Bieri, T., Chinwalla, A., Delehaunty, A., Delehaunty, K., Du, H., Fewell, G., Fulton, L., Fulton, R., Graves, T., Hou, S.F., Latrielle, P., Leonard, S., Mardis, E., Maupin, R., McPherson, J., Miner, T., Nash, W., Nguyen, C., Ozersky, P., Pepin, K., Rock, S., Rohlfing, T., Scott, K., Schultz, B., Strong, C., Tin-Wollam, A., Yang, S.P., Waterston, R.H., Wilson, R.K., Rozen, S., and Page, D.C. (2003) The male-specific region of the human Y chromosome is a mosaic of discrete sequence classes. Nature 423, 825-837.

22. Orr, H.A. and Kim, Y. (1998) An adaptive hypothesis for the evolution of the Y chromosome. Genetics 150, $1693-1698$.

23. Charlesworth, B. and Charlesworth, D. (2000) The degeneration of Y chromosomes. Philos. Trans. R. Soc. Lond. B 355, 1563-1572.

24. Lahn, B.T., Pearson, N.M., and Jegalian, K. (2001) The human Y chromosome in the light of evolution. Nat. Rev. Genet. 2, 207-216.

25. Charlesworth, D., Charlesworth, B., and Martin, G. (2005) Steps in the evolution of heteromorphic sex chromosomes. Heredity 95, 118-128.

26. Charlesworth, B., Sniegowski, P., and Stephan, W. (1994) The evolutionary dynamics of repetitive DNA in eukaryotes. Nature 371, 215-220.

27. Britten, R.Y. and Davidson, E.H. (1969) Gene regulation for higher cells: a theory. Science 165, 349-357.

28. Allen, T.A., von Kaenel, S., Goudrich, J.A., and Kugek, J.F. (2004) The SINE-encoded mouse B2 RNA represses mRNA transcription in response to heat shock. Nat. Struct. Biol. 11, 816-821.

29. Espinoza, C.A., Allen, T.A., Hieb, A., Kugel, J.F., and Goorich, J.A. (2004) B2 RNA binds directly to RNA polymerase II to repress transcript synthesis. Nat. Struct. Mol. Biol. 11, 822-829.

30. Gvozdev, V.A., Kogan, G.L., and Usakin, L.A. (2005) The Y chromosome as a target for acquired and amplified genetic material in evolution. Bioessays 27, 1256-1262.

31. Rice, W.R. (1994) Degeneration of a nonrecombining chromosome. Science 263, 230-232.

32. Balakirev, E.S. and Ayala, F.J. (2003) Pseudogenes: are they ‘junk’ or functional DNA? Annu. Rev. Genet. 37, $123-151$.

33. Lee, J.T. (2003) Complicity of gene and pseudogene. Nature 423, 26-28.

34. Bachtrog, D., Hom, E., Wong, K.M., Maside, X., and de Jong, P. (2008) Genomic degradation of a young Y chromosome in Drosophila miranda. Genome Biol. 9, R30.

35. Bachtrog, D. and Charlesworth, B. (2002) Reduced adaptation of a nonrecombining neo-Y chromosome. Nature 416, 323-326.

36. Waters, P.D., Duffy, B., Frost, C.J., Delbridge, M.L., and Graves, J.A. (2001) The human Y chromosome derives largely from a single autosomal region added to the sex chromosomes 80-130 million years ago. Cytogenet. Cell Genet. 92, 74-79.

37. Koerich, L.B., Wang, X., Clark, A.G., and Carvalho, A.B. (2008) Low conservation of gene content in the Drosophila Y chromosome. Nature 456, 949-951.

38. Carvalho, A.B. and Clark, A.G. (2005) Y chromosome of D. pseudoobscura is not homologous to the ancestral Drosophila Y. Science 307, 108-110.

39. Voelker, R.A. and Kojima, K. (1971) Fertility and fitness of X0 males in Drosophila I. Qualitative study. Evolution 25, 119-128.

40. Hackstein, J.H., Hochstenbach, R., Hauschteck-Jungen, E., and Beukeboom, L.W. (1996) Is the Y chromosome of Drosophila an evolved supernumerary chromosome? Bioessays 18, 317-323.

41. Hollocher, H. and $\mathrm{Wu}$, C.-I. (1996) The genetics of reproductive isolation in the Drosophila simulans clade: X vs. autosomal effects and male vs. female effects. Genetics 143, 1243-1255.

42. Wu, C.-I., Johnson, N.A., and Palopoli, M.F. (1996) Haldane's rule and its legacy: why are there so many sterile males? Trends Ecol. Evol. 11, 281-284.

43. Sawamura, K., Davis, A.W., and Wu, C.-I. (2000) Genetic analysis of speciation by means of introgression into Drosophila melanogaster. Proc. Natl. Acad. Sci. U. S. A. 97, 2652-2655.

44. Tao, Y., Chen, S., Hartl, D.L., and Laurie, C.C. (2003) Genetic dissection of hybrid incompatibilities between Drosophila simulans and D. mauritiana. I. Differential accumulation of hybrid male sterility effects on the $\mathrm{X}$ and autosomes. Genetics 164, 1383-1397.

45. True, J.R., Weir, B.S., and Laurie, C.C. (1996) A genome-wide survey of hybrid incompatibility factors by the introgression of marked segments of Drosophila mauritiana chromosomes into Drosophila simulans. Genetics 142, 819-837.

46. Presgraves, D.C. and Orr, H.A. (1998) Haldane's rule in taxa lacking a hemizygous X. Science 282, 952-954. 
47. Sun, S., Ting, C.T., and Wu, C.-I. (2004) The normal function of a speciation gene, Odysseus, and its hybrid sterility effect. Science 305, 81-83.

48. Ting, C.T., Tsaur, S.C., Sun, S., Browne, W.E., Chen, Y.C., Patel, N.H., and Wu, C.-I. (2004) Gene duplication and speciation in Drosophila: evidence from the Odysseus locus. Proc. Natl. Acad. Sci. U. S. A. 101, 12232-12235.

49. Bayes, J.J. and Malik, H.S. (2009) Altered heterochromatin binding by a hybrid sterility protein in Drosophila sibling species. Science 326, 1538-1541.

50. Sawamura, K., Yamamoto, M.T., and Watanabe, T.K. (1993) Hybrid lethal systems in the Drosophila melanogaster species complex. II. The Zygotic hybrid rescue (Zhr) gene of D. melanogaster. Genetics 133, 307-313.

51. Sawamura, K. and Yamamoto, M.T. (1993) Cytogenetical localization of Zygotic hybrid rescue (Zhr), a Drosophila melanogaster gene that rescues interspecific hybrids from embryonic lethality. Mol. Gen. Genet. 239, 441-449.

52. Ferree, P.M. and Barbash, D.A. (2009) Species-specific heterochromatin prevents mitotic chromosome segregation to cause hybrid lethality in Drosophila. PLoS Biol. 7, e1000234.

53. Brideau, N.J., Flores, H.A., Wang, J., Maheshwari, S., Wang, X., and Barbash, D.A. (2006) Two Dobzhansky-Muller genes interact to cause hybrid lethality in Drosophila. Science 314, 1292-1295.

54. Stern, C. (1929) Untersuchungen über Aberrationen des Y-chromosom von Drosophila melanogaster. Z. Induk. Abstamm. Vererbungsl. 51, 253-353.

55. Kaufmann, B.P. (1933) Interchange between X and Y chromosomes in attached-X females of Drosophila melanogaster. Proc. Natl. Acad. Sci. U. S. A. 19, 830-838.

56. Philip, U. (1935) Crossing over between X and Y chromosomes in Drosophila melanogaster. J. Genet. 31, 341-352.

57. Neuhaus, M.J. (1936) Crossing over between the X and Y chromosomes in the female of Drosophila melanogaster. Z. Induk. Abstamm. Vererbungsl. 71, 265-275.

58. Neuhaus, M.J. (1937) Additional data on crossing over between X and Y chromosomes in Drosophila melanogaster. Genetics 22, 333-339.

59. Lindsley, D.L. (1955) Heterochromatic exchange between a reversed acrocentric compound X chromosome and the Y chromosome. Dros. Inf. Serv. 29, 134.

60. Lindsley, D.L. (1955) Spermatogonial exchange between the X and Y chromosomes of Drosophila melanogaster. Genetics 40, 24-44.

61. Bridges, C.B. (1916) Non-disjunction as proof of the chromosome theory of heredity. Genetics 1, 1-52 and 107-163.

62. Safir, S.R. (1920) Genetic and cytological examination of the phenomenon of primary non-disjunction in Drosophila melanogaster. Genetics 5, 459-487.

63. Stern, C. (1927) Ein genetischer und zytologischer Beweis für Vererbung im Y-chromosome von Drosophila melanogaster. Z. Induk. Abstamm. Vererbungsl. 44, 187-231.

64. Heitz, E. (1934) Über $\alpha$ - and $\beta$-Heterochromatin sowie Konstanz und Bau der Chromomeren bei Drosophila. Biol. Zentralbl. 54, 588-609.

65. Ritossa, F.M., Atwood, K.C., and Spiegelman, S. (1966) A molecular explanation of the bobbed mutants of Drosophila as partial deficiencies of "ribosomal" DNA. Genetics 54, 819-834.

66. Mohan, J. and Ritossa, F.M. (1970) Regulation of ribosomal RNA synthesis and its bearing on the bobbed phenotype in Drosophila melanogaster. Dev. Biol. 22, 495-512.

67. Tartof, K.D. (1973) Regulation of ribosomal RNA gene multiplicity in Drosophila melanogaster. Genetics 73, 57-71.

68. Mohan, J. (1975) The synthesis of 5S RNA and its relationship to 18S and 28S ribosomal RNA in the bobbed mutants of Drosophila melanogaster. Genetics 81, 723-738.

69. Shermoen, A.W. and Kiefer, B.I. (1975) Regulation in rDNA-deficient Drosophila melanogaster. Cell 4, $275-280$.

70. McKee, B.D. and Karpen, G.H. (1990) Drosophila ribosomal RNA gene function as a X-Y pairing site during meiosis. Cell 61, 61-72.

71. Muller, H.J. and Painter, T.S. (1932) The differentiation of the sex chromosome of Drosophila melanogaster into genetically active and inert regions. Z. Induk. Abstamm. Vererbungsl. 62, 316-365.

72. Heitz, E. (1933) Cytologische Untersuchungen an Dipteren III., Die somatische Heteropyknose bei Drosophila melanogaster und ihre genetische Bedeutung. Z. Zellforsch. 20, 237-287.

73. Hoskins, R.A., Carlson, J.W., Kennedy, C., Acevedo, D., Evans-Holm, M., Frise, E., Wan, K.H., Park, S., MendezLago, M., Rossi, F., Villasante, A., Dimitri, P., Karpen, G.H., and Celniker, S.E. (2007) Sequence finishing and mapping of Drosophila melanogaster heterochromatin. Science 316, 1625-1628.

74. Smith, C.D., Shu, S., Mungall, C.J., and Karpen, G.H. (2007) The Release 5.1 annotation of Drosophila melanogaster heterochromatin. Science 316, 1586-1591. Erratum in: Science 317, 1325.

75. Pimpinelli, S., Santini, G., and Gatti, M. (1976) Characterization of Drosophila heterochromatin. II. C- and Nbanding. Chromosoma 57, 377-386.

76. Bonaccorsi, S. and Lohe, A. (1991) Fine mapping of satellite DNA sequences along the Y chromosome of Drosophila melanogaster: relationships between satellite sequences and fertility factors. Genetics 129, 177-189.

77. Lohe, A.R., Hilliker, A.J., and Roberts, P.A. (1993) Mapping simple repeated DNA sequences in heterochromatin of Drosophila melanogaster. Genetics 134, 1149-1174.

78. Gatti, M. and Pimpinelli, S. (1992) Functional elements in Drosophila melanogaster heterochromatin. Annu. Rev. Genet. 26, 239-275. 
79. Pimpinelli, S., Berloco, M., Fanti, L., Dimitri, P., Bonaccorsi, S., Marchetti, E., Caizzi, R., Caggese, C., and Gatti, M. (1995). Transposable elements are stable structural components of Drosophila melanogaster heterochromatin. Proc. Natl. Acad. Sci. U. S. A. 92, 3804-3808.

80. Berloco, M., Fanti, L., Sheen, F., Levis, R.W., and Pimpinelli, S. (2005) Heterochromatic distribution of HeT-A- and TART-like sequences in several Drosophila species. Cytogenet. Genome Res. 110, 124-133.

81. Brosseau, G.E. (1960) Genetic analysis of the male fertility factors on the Y chromosome of Drosophila melanogaster. Genetics 45, 257-274.

82. Russell, S.R.H. and Kaiser, K. (1993) Drosophila melanogaster male germ line-specific transcripts with autosomal and Y-linked genes. Genetics 134, 293-308.

83. Gepner, J. and Hays, T.S. (1993) A fertility region on the Y chromosome of Drosophila melanogaster encodes a dynein microtubule motor. Proc. Natl. Acad. Sci. U. S. A. 90, 11132-11136.

84. Carvalho, A.B., Lazzaro, B.P., and Clark, A.G. (2000) Y chromosomal fertility factors $k l-2$ and $k l-3$ of Drosophila melanogaster encode dynein heavy chain polypeptides. Proc. Natl. Acad. Sci. U. S. A. 97, 13239-13244.

85. Carvalho, A.B., Dobo, B.A., Vibranovski, M.D., and Clark, A.G. (2001) Identification of five new genes on the Y chromosome of Drosophila melanogaster. Proc. Natl. Acad. Sci. U. S. A. 98, 13225-13230.

86. Vibranovski, M.D., Koerich, L.B., and Carvalho, A.B. (2008) Two new Y-linked genes in Drosophila melanogaster. Genetics 179, 2325-2327.

87. Krsticevic, F.J., Santos, H.L., Januário, S., Schrago, C.G., and Carvalho, A.B. (2010) Functional copies of the Mst77F gene on the Y chromosome of Drosophila melanogaster. Genetics 184, 295-307.

88. Piergentili, R. and Mencarelli, C. (2008) Drosophila melanogaster kl-3 and kl-5 Y-loops harbor triple-stranded nucleic acids. J. Cell Sci. 121, 1605-1612.

89. Carvalho, A.B. and Clark, A.G. (2003) Birth of a new gene on the Drosophila Y chromosome. Abstracts of the 44th Annual Drosophila Research Conference, March 2003, Chicago. 318C.

90. Salz, H.K. and Erickson, J.W. (2010) Sex determination in Drosophila: the view from the top. Fly (Austin) 4, 60-70.

91. Schotta, G., Ebert, A., Dorn, R., and Reuter, G. (2003) Position-effect variegation and the genetic dissection of chromatin regulation in Drosophila. Semin. Cell Dev. Biol. 14, 67-75.

92. Gowen, J.W. and Gay, E.H. (1933) Eversporting as a function of the Y chromosome in Drosophila melanogaster. Proc. Natl. Acad. Sci. U. S. A. 19, 122-126.

93. Gowen, J.W. and Gay, E.H. (1934) Chromosome constitution and behavior in eversporting and mottling in Drosophila melanogaster. Genetics 19, 189-208.

94. Dubinin, N.P. and Heptner, M.A. (1935) A new phenotypic effect of the Y chromosome in Drosophila melanogaster. J. Genet. 30, 423-446.

95. Schultz, J. (1936) Variegation in Drosophila and the inert chromosome regions. Proc. Natl. Acad. Sci. U. S. A. 22, 27-33.

96. Dimitri, P. and Pisano, C. (1989) Position effect variegation in Drosophila melanogaster: relationship between suppression effect and the amount of Y chromosome. Genetics 122, 793-800.

97. Becker, H.J. and Janning, W. (1977) Heterochromatin of the Drosophila melanogaster Y chromosome as modifier of position effect variegation: the time of its action. Mol. Gen. Genet. 151, 111-114.

98. Noujdin, N.I. (1936) Influence of the Y chromosome and of the homologous region of the X on mosaicism in Drosophila. Nature 137, 319-320.

99. Levenbook, L., Travaglini, E.C., and Schultz, J. (1958) Nucleic acids and their components as affected by the Y chromosome of Drosophila melanogaster. I. Constitution and amount of the ribonucleic acids in the unfertilized egg. Exp. Cell Res. 15, 43-61.

100. Travaglini, E.C., Levenbook, L., and Schultz, J. (1958) Nucleic acids and their components as affected by the Y chromosome of Drosophila melanogaster. II. The nucleosides and related compounds in the acid soluble fraction of the unfertilized egg. Exp. Cell Res. 15, 62-79.

101. Cooper, K.W. (1956) Phenotypic effects of Y chromosome hyperploidy in Drosophila melanogaster and their relation to variegation. Genetics 41, 242-264.

102. Morgan, T.H., Bridges, C.B., and Schultz, J. (1934) Constitution of the germinal material in relation to heredity. Carnegie Inst. Wash. Ybk. 33, 274-280.

103. Stern, C. (1929) Uber die additive Wirkung multipler Allele. Biol. Zentralbl. 49, 261-290.

104. Cooper, K.W. (1959) Cytogenetic analysis of major heterochromatic elements (especially Xh and Y) in Drosophila melanogaster, and the theory of "heterochromatin". Chromosoma 10, 535-588.

105. Kennison, J.A. (1981) The genetical and cytological organization of the Y chromosome of Drosophila melanogaster. Genetics 98, 529-548.

106. Hazelrigg, T., Fornili, P., and Kaufman, T.C. (1982) A cytogenetic analysis of X-ray induced male steriles on the Y chromosome of Drosophila melanogaster. Chromosoma 87, 535-559.

107. Gatti, M. and Pimpinelli, S. (1983) Cytological and genetic analysis of the Y chromosome of Drosophila melanogaster. I. Organization of the fertility factors. Chromosoma 88, 349-373.

108. Marsh, J.L. and Wieschaus, E. (1978) Is sex determination in germ line and soma controlled by separate genetic mechanisms? Nature 272, 249-251. 
109. Lindsley, D.L. and Tokuyasu, K.T. (1980) Spermatogenesis. In The Genetics and Biology of Drosophila. Vol. 2. Ashburner, M. and Wright, T.R.F., Eds. Academic Press. New York. pp. 225-294.

110. Bonaccorsi, S., Pisano, C., Puoti, F., and Gatti, M. (1988) Y chromosome loops in Drosophila melanogaster. Genetics 120, 1015-1034.

111. Piergentili, R. (2007) Evolutionary conservation of lampbrush-like loops in drosophilids. BMC Cell Biol. 8, 35.

112. Piergentili, R. (2006) A simple method to prepare DNA fibres in the male germ line. Dros. Info. Serv. 89, 128-130

113. Saumweber, H., Symmons, P., Kabish, R., Will, H., and Bonhoeffer, F. (1980) Monoclonal antibodies against chromosomal proteins of Drosophila melanogaster. Chromosoma 80, 253-275.

114. Risau, W., Symmons, P., Saumweber, H., and Frash, M. (1983) Nonpackaging and packaging proteins of hnRNA in Drosophila melanogaster. Cell 33, 529-541.

115. Hulsebos, T.J., Hackstein, J.H., and Hennig, W. (1984) Lampbrush loop-specific protein of Drosophila hydei. Proc. Natl. Acad. Sci. U. S. A. 81, 3404-3408.

116. Melzer, S. and Glätzer, K.H. (1985) Localization of RNP antigens in primary spermatocytes of Drosophila melanogaster by indirect immunofluorescence and their correlation to fertility factors. Dros. Info. Serv. 61, 121.

117. Pisano, C., Bonaccorsi, S., and Gatti, M. (1993) The kl-3 loop of the Y chromosome of Drosophila melanogaster binds a tektin-like protein. Genetics 133, 569-579.

118. Gatti, M. (1995) Genetic and molecular organization of the Y chromosome fertility factors of Drosophila melanogaster. Sci. Rep. Inst. Pasteur, Roma 1991-1994 1995, 25-26.

119. Eberhart, C.G., Maines, J.Z., and Wasserman, S.A. (1996) Meiotic cell cycle requirement for a fly homologue of human Deleted in Azoospermia. Nature 381, 783-785.

120. Heatwole, V.M. and Haynes, S.R. (1996) Association of RB97D, an RRM protein required for male fertility, with a Y chromosome lampbrush loop in Drosophila spermatocytes. Chromosoma 105, 285-292.

121. Cheng, M.H., Maines, J.Z., and Wasserman, S.A. (1998) Biphasic subcellular localization of the DAZL-related protein Boule in Drosophila spermatogenesis. Dev. Biol. 20, 567-576.

122. Lu, A.Q. and Beckingham, K. (2000) Androcam, a Drosophila calmodulin-related protein, is expressed specifically in the testis and decorates loop kl-3 of the Y chromosome. Mech. Dev. 94, 171-181.

123. Marhold, J., Zbylut, M., Lankenau, D.H., Li, M., Gerlich, D., Ballestar, E., Mechler, B.M., and Lyko, F. (2002) Stagespecific chromosomal association of Drosophila dMBD2/3 during genome activation. Chromosoma 111, 13-21.

124. Svensson, M.J., Chen, J.D., Pirrotta, V., and Larsson, J. (2003) The ThioredoxinT and deadhead gene pair encode testis- and ovary-specific thioredoxins in Drosophila melanogaster. Chromosoma 112, 133-143.

125. Frank, D.J., Martin, S.R., Gruender, B.N., Lee, Y.S., Simonette, R.A., Bayley, P.M., Miller, K.G., and Beckingham, K.M. (2006) Androcam is a tissue-specific light chain for myosin VI in the Drosophila testis. J. Biol. Chem. 281, 24728-24736.

126. Adams, M.D., Celniker, S.E., Holt, R.A., Evans, C.A., Gocayne, J.D., Amanatides, P.G., Scherer, S.E., Li, P.W., Hoskins, R.A., Galle, R.F., George, R.A., Lewis, S.E., Richards, S., Ashburner, M., Henderson, S.N., Sutton, G.G., Wortman, J.R., Yandell, M.D., Zhang, Q., Chen, L.X., Brandon, R.C., Rogers, Y.H., Blazej, R.G., Champe, M., Pfeiffer, B.D., Wan, K.H., Doyle, C., Baxter, E.G., Helt, G., Nelson, C.R., Gabor, G.L., Abril, J.F., Agbayani, A., An, H.J., Andrews-Pfannkoch, C., Baldwin, D., Ballew, R.M., Basu, A., Baxendale, J., Bayraktaroglu, L., Beasley, E.M., Beeson, K.Y., Benos, P.V., Berman, B.P., Bhandari, D., Bolshakov, S., Borkova, D., Botchan, M.R., Bouck, J., Brokstein, P., Brottier, P., Burtis, K.C., Busam, D.A., Butler, H., Cadieu, E., Center, A., Chandra, I., Cherry, J.M., Cawley, S., Dahlke, C., Davenport, L.B., Davies, P., de Pablos, B., Delcher, A., Deng, Z., Mays, A.D., Dew, I., Dietz, S.M., Dodson, K., Doup, L.E., Downes, M., Dugan-Rocha, S., Dunkov, B.C., Dunn, P., Durbin, K.J., Evangelista, C.C., Ferraz, C., Ferriera, S., Fleischmann, W., Fosler, C., Gabrielian, A.E., Garg, N.S., Gelbart, W.M., Glasser, K., Glodek, A., Gong, F., Gorrell, J.H., Gu, Z., Guan, P., Harris, M., Harris, N.L., Harvey, D., Heiman, T.J., Hernandez, J.R., Houck, J., Hostin, D., Houston, K.A., Howland, T.J., Wei, M.H., Ibegwam, C., Jalali, M., Kalush, F., Karpen, G.H., Ke, Z., Kennison, J.A., Ketchum, K.A., Kimmel, B.E., Kodira, C.D., Kraft, C., Kravitz, S., Kulp, D., Lai, Z., Lasko, P., Lei, Y., Levitsky, A.A., Li, J., Li, Z., Liang, Y., Lin, X., Liu, X., Mattei, B., McIntosh, T.C., McLeod, M.P., McPherson, D., Merkulov, G., Milshina, N.V., Mobarry, C., Morris, J., Moshrefi, A., Mount, S.M., Moy, M., Murphy, B., Murphy, L., Muzny, D.M., Nelson, D.L., Nelson, D.R., Nelson, K.A., Nixon, K., Nu sskern, D.R., Pacleb, J.M., Palazzolo, M., Pittman, G.S., Pan, S., Pollard, J., Puri, V., Reese, M.G., Reinert, K., Remington, K., Saunders, R.D., Scheeler, F., Shen, H., Shue, B.C., Sidén-Kiamos, I., Simpson, M., Skupski, M.P., Smith, T., Spier, E., Spradling, A.C., Stapleton, M., Strong, R., Sun, E., Svirskas, R., Tector, C., Turner, R., Venter, E., Wang, A.H., Wang, X., Wang, Z.Y., Wassarman, D.A., Weinstock, G.M., Weissenbach, J., Williams, S.M., Woodage, T., Worley, K.C., Wu, D., Yang, S., Yao, Q.A., Ye, J., Yeh, R.F., Zaveri, J.S., Zhan, M., Zhang, G., Zhao, Q., Zheng, L., Zheng, X.H., Zhong, F.N., Zhong, W., Zhou, X., Zhu, S., Zhu, X., Smith, H.O., Gibbs, R.A., Myers, E.W., Rubin, G.M., and Venter, J.C. (2000) The genome sequence of Drosophila melanogaster. Science 287, 2185-2195.

127. Carvalho, A.B., Vibranovski, M.D., Carlson, J.W., Celniker, S.E., Hoskins, R.A., Rubin, G.M., Sutton, G.G., Adams, M.D., Myers, E.W., and Clark, A.G. (2003) Y chromosome and other heterochromatic sequences of the Drosophila melanogaster genome: how far can we go? Genetica 117, 227-237.

128. Young, W.C. and Plough, H.H. (1926) On the sterilization of Drosophila by high temperature. Biol. Bull. 51, $189-198$. 
129. David, J., Arens, M.F., and Cohet, Y. (1971) Sterilite male at haute temperature chez Drosophila melanogaster: nature, progressivite et reversibilite des effets de la chaleur. C. R. Hebd. Seances Acad. Sci. Ser. D Sci. Nat. 272, 1007-1010.

130. Pétavy, G., David, J.R., Gibert, P., and Moreteau, B. (2001) Viability and rate of development at different temperatures in Drosophila: a comparison of constant and alternating thermal regimes. J. Therm. Biol. 26, 29-39.

131. Parsons, P.A. (1973) Genetic of resistance to environmental stresses in Drosophila populations. Annu. Rev. Genet. 7, 239-265.

132. David, J.R., Araripe, L.O., Chakir, M., Legout, H., Lemos, B., Pétavy, G., Rohmer, C., Joly, D., and Moreteau, B. (2005) Male sterility at extreme temperatures: a significant but neglected phenomenon for understanding Drosophila climatic adaptations. J. Evol. Biol. 18, 838-846.

133. Kuznetsova, O.V. (1994) Genetic analysis of a temperature-resistant-line of Drosophila melanogaster Meigen. Genetika 30, 903-905.

134. Zatsepina, O.G., Velikodvorskaia, V.V., Molodtsov, V.B., Garbuz, D., Lerman, D.N., Bettencourt, B.R., Feder, M.E., and Evgenev, M.B. (2001) A Drosophila melanogaster strain from sub-equatorial Africa has exceptional thermotolerance but decreased Hsp70 expression. J. Exp. Biol. 204, 1869-1881.

135. Rohmer, C., David, J.R., Moreteau, B., and Joly, D. (2004) Heat induced male sterility in Drosophila melanogaster: adaptive genetic variations among geographic populations and role of the Y chromosome. J. Exp. Biol. 207, 2735-2743.

136. Chakir, M., Chafik, A., Moreteau, B., Gibert, P., and David, J.R. (2002) Male sterility thermal thresholds in Drosophila: D. simulans appears more cold-adapted than its sibling D. melanogaster. Genetica 114, 195-205.

137. Vollmer, J.H., Sarup, P., Kaersgaard, C.W., Dahlgaard, J., and Loeschcke, V. (2004) Heat and cold induced male sterility in Drosophila buzzatii, genetic variation populations for the duration of sterility. Heredity 92, 257-262.

138. Araripe, L.O., Klaczko, L.B., Moreteau, B., and David, J.R. (2004) Male sterility thresholds at extreme temperatures in a tropical drosophilid Zaprionus indianus. J. Therm. Biol. 29, 73-80.

139. Hardy, R.W., Tokuyasu, K.T., and Lindsley, D.L. (1981) Analysis of spermatogenesis in Drosophila melanogaster bearing deletions for Y-chromosome fertility genes. Chromosoma 83, 593-617.

140. Ayles, G.B., Sanders, T.G., Kiefer, B.I., and Suzuki, D.T. (1973) Temperature-sensitive mutations in Drosophila melanogaster. XI. Male sterile mutants of the Y chromosome. Dev. Biol. 32, 239-257.

141. Felsenfeld, G., Davies, D.R., and Rich, A. (1957) Formation of a three-stranded polynucleotide molecule. J. Am. Chem. Soc. 79, 2023-2024.

142. Lee, J.S., Burkholder, G.D., Latimer, L.J.P., Haug, B.L., and Braun, R.P. (1987) A monoclonal antibody to triplex DNA binds to eukaryotic chromosomes. Nucleic Acids Res. 15, 1047-1061.

143. Burkholder, G.D., Latimer, L.J.P., and Lee, J.S. (1988) Immunofluorescent staining of mammalian nuclei and chromosomes with a monoclonal antibody to triplex DNA. Chromosoma 97, 185-192.

144. Lee, J.S., Latimer, L.J., Haug, B.L., Pulleyblank, D.E., Skinner, D.M., and Burkholder, G.D. (1989) Triplex DNA in plasmids and chromosomes. Gene 82, 191-199.

145. Agazie, Y.M., Lee, J.S., and Burkholder, G.D. (1994) Characterization of a new monoclonal antibody to triplex DNA and immunofluorescent staining of mammalian chromosomes. J. Biol. Chem. 269, 7019-7023.

146. Mol, C.D., Muir, A.K.S., Cygler, M., Lee, J.S., and Anderson, W.F. (1994) Structure of an immunoglobulin Fab fragment specific for triple-stranded DNA. J. Biol. Chem. 269, 3615-3622.

147. Agazie, Y.M., Burkholder, G.D., and Lee, J.S. (1996) Triplex DNA in the nucleus: direct binding of triplex-specific antibodies and their effect on transcription, replication and cell growth. Biochem. J. 316, 461-466.

148. Goldstein, L.S.B., Hardy, R.W., and Lindsley, D.L. (1982) Structural genes on the Y chromosome of Drosophila melanogaster. Proc. Natl. Acad. Sci. U. S. A. 79, 7405-7409.

149. Piergentili, R., Bonaccorsi, S., Raffa, G.D., Pisano, C., Hackstein, J.H.P., and Mencarelli, C. (2004) Autosomal control of the Y-chromosome kl-3 loop of Drosophila melanogaster. Chromosoma 113, 188-196.

150. Ceprani, F., Raffa, G.D., Petrucci, R., and Piergentili, R. (2008) Autosomal mutations affecting Y chromosome loops in Drosophila melanogaster. BMC Genet. 9, 32.

151. Hackstein, J.H.P. and Hochstenbach, R. (1995) The elusive fertility genes of Drosophila: the ultimate haven for selfish genetic elements. Trends Genet. 11, 195-200.

152. Kurek, R.A., Reugels, M., Lammermann, U., and Bünemann, H. (2000) Molecular aspects of intron evolution in dynein encoding mega-genes on the heterochromatic Y chromosome of Drosophila sp. Genetica 109, 113-123.

153. Reugels, A.M., Kurek, R.A., Lammermann, U., and Bünemann, H. (2000) Mega-introns in the dynein gene $\operatorname{DhDhc7}(Y)$ on the heterochromatic Y chromosome give rise to the giant Threads loops in spermatocytes of Drosophila hydei. Genetics 154, 759-769.

154. Chippindale, A.K. and Rice, W.R. (2001) Y chromosome polymorphism is a strong determinant of male fitness in Drosophila melanogaster. Proc. Natl. Acad. Sci. U. S. A. 98, 5677-5682.

155. Carvalho, A.B., Vaz, S.C., and Klaczko, L.B. (1997) Polymorphism for Y-linked suppressors of sex-ratio in two natural populations of Drosophila mediopunctata. Genetics 146, 891-902.

156. Montchamp-Moreau, C., Ginhoux, V., and Atlan, A. (2001) The Y chromosomes of Drosophila simulans are highly polymorphic for their ability to suppress sex-ratio drive. Evolution 55, 728-737.

157. Stoltenberg, S.F. and Hirsch, J. (1997) Y-chromosome effects on Drosophila geotaxis interact with genetic or cytoplasmic background. Anim. Behav. 53, 853-864. 
158. Huttunen, S. and Aspi, J. (2003) Complex inheritance of male courtship song characters in Drosophila virilis. Behav. Genet. 33, 17-24.

159. Lemos, B., Araripe, L.O., and Hartl, D.L. (2008) Polymorphic Y chromosomes harbor cryptic variation with manifold functional consequences. Science 319, 91-93.

160. Rice, W.R. and Friberg, U. (2008) Genetics. Functionally degenerate - Y not so? Science 319, $42-43$.

161. Malone, J.H. and Oliver, B. (2008) The sex chromosome that refused to die. Bioessays 30, 409-411.

162. Lifschytz, E. (1987) The genetic control of spermatogenesis. Int. Rev. Cytol. 109, 211-258.

163. Pitnick, S., Markow, T.A., and Spicer, G.S. (1995) Delayed male maturity is a cost of producing large sperm in Drosophila. Proc. Natl. Acad. Sci. U. S. A. 92, 10614-10618.

164. Pitnick, S., Spicer, G.S., and Markow, T.A. (1995) How long is a giant sperm? Nature 375, 109.

165. Aitken, J.R. and Graves, J.A. (2002) Human spermatozoa: the future of sex. Nature 415, 963.

166. Graves, J.A. (2004) The degenerate Y chromosome - can conversion save it? Reprod. Fertil. Dev. 16, $527-534$.

167. Menon, D.U. and Meller, V.H. (2009) Imprinting of the Y chromosome influences dosage compensation in roX1 roX2 Drosophila melanogaster. Genetics 183, 811-820.

168. Golic, K.G., Golic, M.M., and Pimpinelli, S. (1998) Imprinted control of gene activity in Drosophila. Curr. Biol. 8, 1273-1276.

169. Haller, B.S. and Woodruff, R.C. (2000) Varied expression of a Y-linked $\mathrm{P}[\mathrm{w}+]$ insert due to imprinting in Drosophila melanogaster. Genome 43, 285-892.

170. Maggert, K.A. and Golic, K.G. (2002) The Y chromosome of Drosophila melanogaster exhibits chromosome-wide imprinting. Genetics 162, 1245-1258.

171. Lucchesi, J.C., Kelly, W.G., and Panning, B. (2005) Chromatin remodeling in dosage compensation. Annu. Rev. Genet. 39, 615-651.

172. Mendjan, S. and Akhtar, A. (2007) The right dose for every sex. Chromosoma 116, 95-106.

173. Meller, V.H. and Rattner, B.P. (2002) The $r o X$ genes encode redundant male-specific lethal transcripts required for targeting of the MSL complex. EMBO J. 21, 1084-1091.

174. Tilford, C.A., Kuroda-Kawaguchi, T., Skaletsky, H., Rozen, S., Brown, L.G., Rosenberg, M., McPherson, J.D., Wylie, K., Sekhon, M., Kucaba, T.A., Waterson, R.H., and Page, D.C. (2001) A physical map of the human Y chromosome. Nature 409, 943-945.

175. Lange, J., Skaletsky, H., van Daalen, S.K.M., Embry, S.L., Korver, C.M., Brown, L.G., Oates, R.D., Silber, S., Repping, S., and Page, D.C. (2009) Isodicentric Y chromosomes and sex disorders as byproducts of homologous recombination that maintains palindromes. Cell 138, 855-869.

176. Repping, S., van Daalen, S.K.M., Brown, L.G., Korver, C.M., Lange, J., Marszalek, J.D., Pyntikova, T., van der Veen, F., Skaletsky, H., Page, D.C., and Rozen, S. (2006) High mutation rates have driven extensive structural polymorphism among human Y chromosomes. Nat. Genet. 38, 463-467.

177. Page, D.C., Harper, M.E., Love, J., and Botstein, D. (1984) Occurrence of a transposition from the X-chromosome long arm to the Y-chromosome short arm during human evolution. Nature 311, 119-123.

178. Mumm, S., Molini, B., Terrell, J., Srivastava, A., and Schlessinger, D. (1997) Evolutionary features of the 4-Mb Xq21.3 XY homology region revealed by a map at 60-kb resolution. Genome Res. 7, 307-314.

179. Schwartz, A., Chan, D.C., Brown, L.G., Alagappan, R., Pettay, D., Disteche, C., McGillivray, B., de la Chapelle, A., and Page, D.C. (1998) Reconstructing hominid Y evolution: X-homologous block, created by X-Y transposition, was disrupted by Yp inversion through LINE-LINE recombination. Hum. Mol. Genet. 7, 1-11.

180. Kuroda-Kawaguchi, T., Skaletsky, H., Brown, L.G., Minx, P.J., Cordum, H.S., Waterston, R.H., Wilson, R.K., Silber, S., Oates, R., Rozen, S., and Page, D.C. (2001) The AZFc region of the Y chromosome features massive palindromes and uniform recurrent deletions in infertile men. Nat. Genet. 29, 279-286.

181. Seshagiri, P.B. (2001) Molecular insights into the causes of male infertility. J. Biosci. 26, 429-435.

182. Sadeghi-Nejad H. and Oates, RD (2008). The Y chromosome and male infertility. Curr. Opin. Urol. 18, 628-632.

183. Li, Z., Haines, C.J., and Han, Y. (2008) "Micro-deletions" of the human Y chromosome and their relationship with male infertility. J. Genet. Genomics 35, 193-199.

184. Foresta, C., Moro, E., and Ferkin, A. (2001) Y chromosome microdeletions and alterations of spermatogenesis. Endocr. Rev. 22, 226-239.

185. Vogt, P.H., Falcao, C.L., Hanstein, R., and Zimmer, J. (2008) The AZF proteins. Int. J. Androl. 31, $383-394$.

186. Gatta, V., Stuppia, L., Calabrese, G., Morizio, E., Guanciali-Franchi, P., and Palka, G. (2002) A new case of Yq microdeletion transmitted from a normal father to two infertile sons. J. Med. Genet., 39, E27.

187. Nazareko, S.A., Puzyrev, V.P., and Lemza, S.V. (1991) Y chromosome heterochromatin and human morphophysiological variability. Acta Genet. Sin. 18, 424-430 (in Chinese with an English abstract).

\section{This article should be cited as follows:}

Piergentili, R. (2010) Multiple roles of the Y chromosome in the biology of Drosophila melanogaster. TheScientificWorldJOURNAL 10, 1749-1767. DOI 10.1100/tsw.2010.168. 

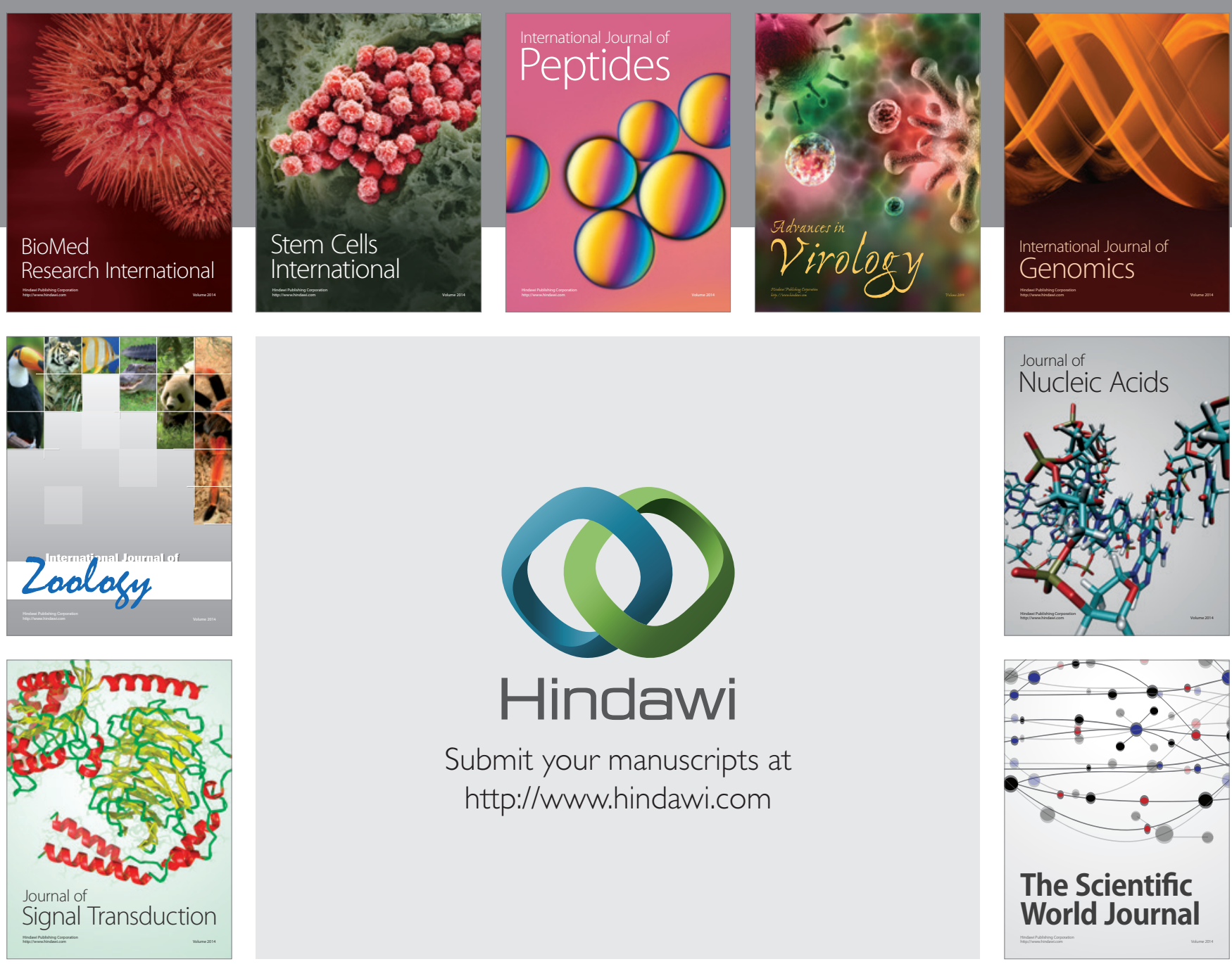

Submit your manuscripts at

http://www.hindawi.com
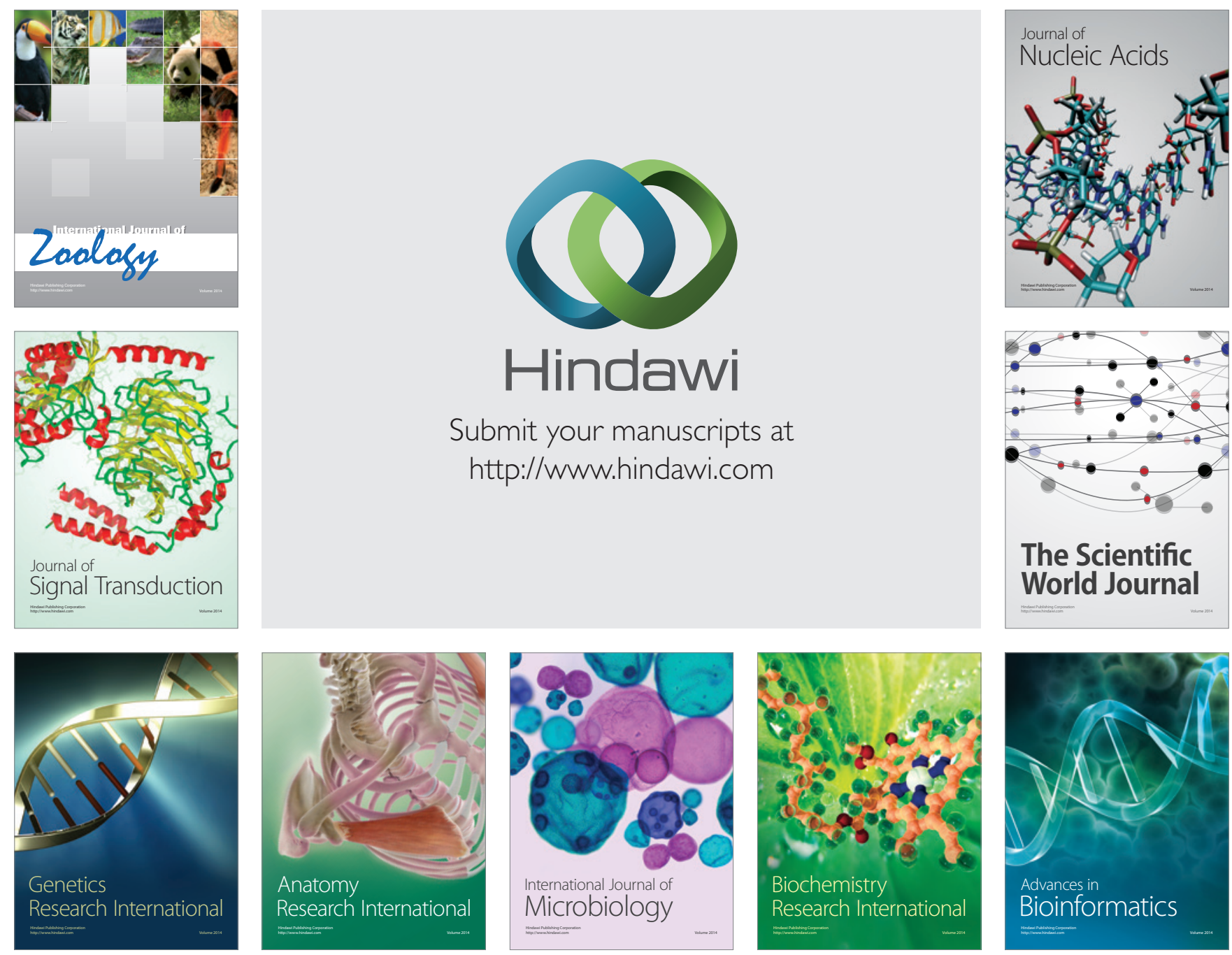

The Scientific World Journal
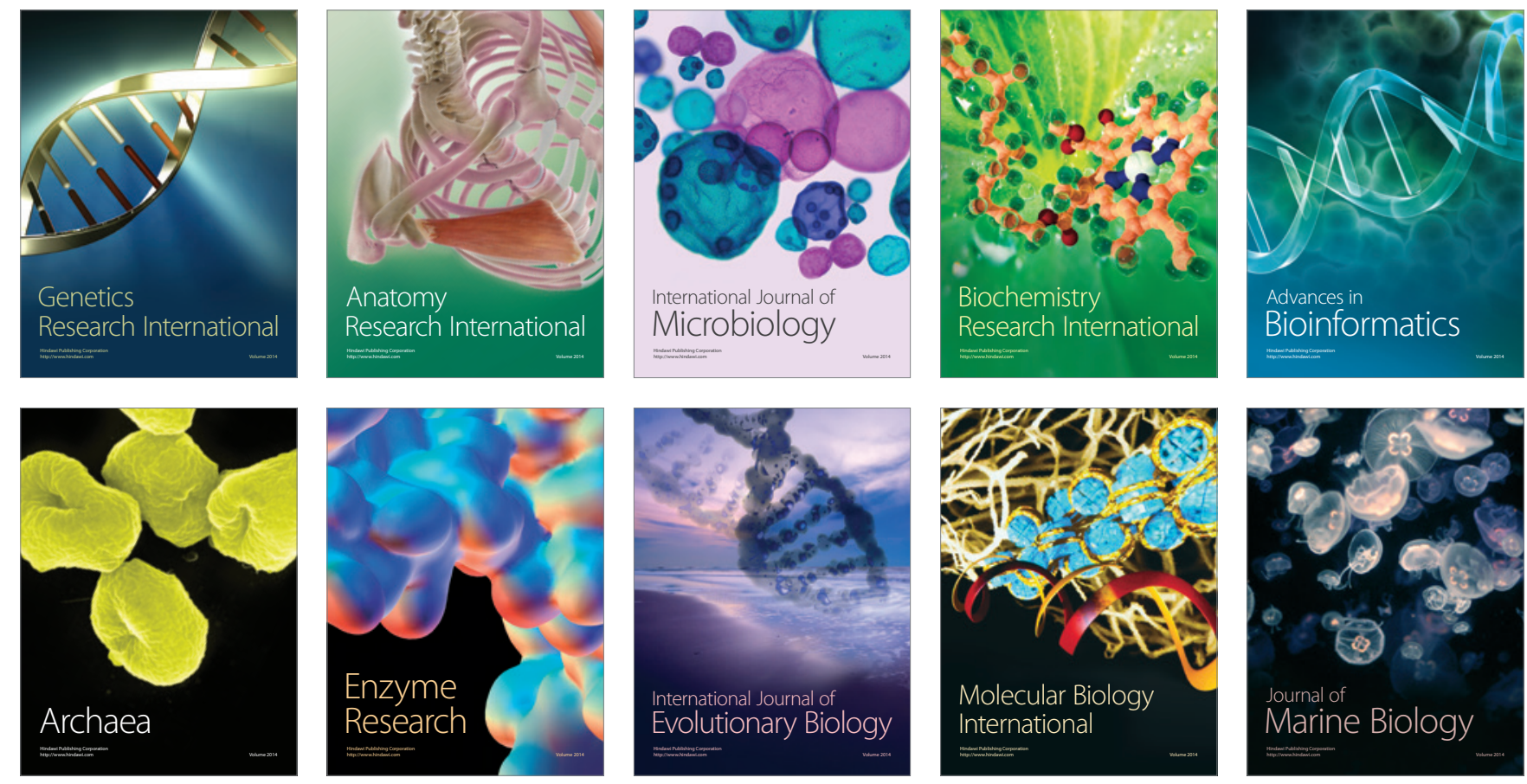